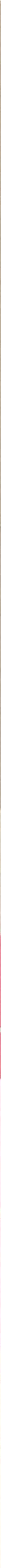



Streamflow, Sediment-Transport, and Water-Temperature Characteristics of Three Small Watersheds in the Alsea River Basin, Oregon

By D. D. Harris and R. C. Williams

GEOLOGICAL SURVEY CIRCULAR 642

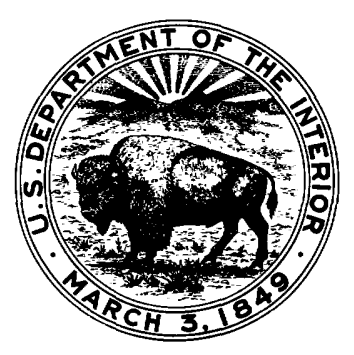


United States Department of the Interior ROGERS C. B. MORTON, Secretary

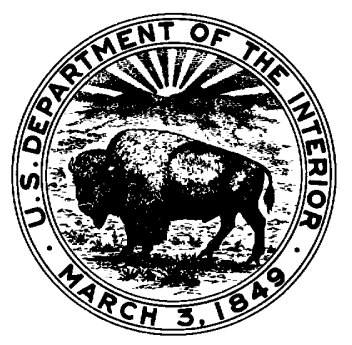

Geological Survey

W. A. Radlinski, Acting Director 


\section{CONTENTS}

Definition of terms

Abstract

Introduction

Hydrologic environment

Data collected and methods used

Precipitation

Streamflow

Sediment transport

Water temperatures

Analysis and interpretation of data

Precipitation

Streamflow
Page

iv

1

1

2

3

3

3

3

4

4

5

5

Analysis and interpretation of data-Continurd Streamflow-Continued Distribution and volume of runoff --.- $\quad$ 5

High flow -_..-_-_._-_._- 9

Low flow -_-

Sediment transport _.-_-_-_-_-_-_-_--- 12

Sediment concentration

Sediment load _-_-_-_-_-_-_-_-_-- 14

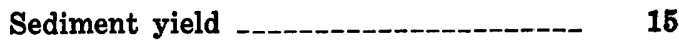

Water temperatures --.--_- 16

Summary --_-_-_-_-_-_-_-_-_-_-_--- 19

Selected references

\section{ILLUSTRATIONS}

Figure 1. Map showing the study area

2-19. Graphs showing-

2. Relation of annual precipitation at Needle Branch and at Deer Creek gages th that at the Flynn Creek gage

3. Duration curves of discharge for the three study streams

4. Range and seasonal distribution of flows for Needle Branch and Deer Creek ----

5. Relation of annual runoff of Needle Branch and of Deer Creek to that of Flyn n Creek for water years 1959-65

6. Relation of seasonal runoff of Needle Branch and of Deer Creek to that of Flynn

Creek for water years 1959-65
7. Relation of peak flow of Needle Branch and of Deer Creek to that of Flynn Creek for water years 1959-65

8. Relation of 3-day high-flow runoff of Needle Branch and of Deer Creek to thet: of Flynn Creek for water years 1959-65

9. Low-flow recession rates for Needle Branch and Deer Creek for water years 1959-65

10. Relation of low flow of Needle Branch and of Deer Creek to that of Flynn Creet for water years 1959-65

11. Duration curves of suspended-sediment concentracions for streams

12. Relation of annual discharge-weighted mean concentration of Needle Branch and of Deer Creek to that of Flynn Creek for water years 1959-65

13. Relation of monthly sediment yield of Needle Branch and of Deer Creek water: sheds to that of Flynn Creek watershed for water years 1959-65

14. Relation of annual sediment yield of Needle Branch and of Deer Creek watersheds to that of Flynn Creek watershed for water years 1959-65

15. Relation of maximum water temperature of Needle Branch and of Deer Creek to that of Flynn Creek for water years 1959-65 

Branch and of Deer Creek to that of Flynn Creek for water years 1959-65 --

17. Relation of minimum water temperature of Needle Branch and of Deer Creek to that of Flynn Creek for water years 1959-65

18. Relation of monthly average of minimum daily water temperature of Needle

18. Relation of monthly average of minimum daily water temperature of Needle
Branch and of Deer Creek to that of Flynn Creek for water years $1959-65$

19. Relation of monthly water-temperature range of Needle
Creek to that of Flynn Creek for water years $1959-65$

\section{TABLES}

TABLE 1. Annual precipitation, in inches, measured at the precipitation gages, and differences from that measured at the Flynn Creek gage

2. Annual runoff for each year of the calibration period

3. Peak discharge and runoff for all peaks greater than 50 cfs per sq mi on Flynn Creel: and

concurrent peaks on Needle Branch and Deer Creek
4. Three-day high-flow runoff for Flynn Creek, Needle Branch, and Deer Creek

5. Approximate composition of suspended-sediment load during the calibration period

6. Particle-size distribution of sediment deposited behind the concrete control weirs for the dates given

7. Annual sediment yields, in tons per square mile, of the three principal watersheds for 1959-65

\section{DEFINITION OF TERMS}

Bedload is the sediment (1) that moves by sliding, rolling, or skipping on or very near the streambed, and (2) sediment that is moved by tractive or gravitational forces, or both, but at velocities less than those of the adjacent flow.

Cubic feet per second (cfs) is the rate of discharge of a stream whose channel is 1 square foot in crosssectional area and whose average velocity is 1 foot per second.

Cubic feet per second per square mile (cfs per sq mi) is the average number of cubic feet of water flowing per second from each square mile of area drained, assuming that the runoff is distributed uniformly in time and area.

Discharge-weighted mean sediment concentration is the theoretical sediment concentration if all the water and sediment passing a section during a time interval were mixed; concentrations are expressed in parts per million (ppm).

Gaging station is a particular site on a stream, canal, lake, or reservoir where systematic observations of gage height or discharge are obtained. When used in connection with a discharge record, the term is applied only to those gaging stations where a continuous record of discharge is obtained.

Particle size is the diameter, in millimeters $(\mathrm{mm})$, of suspended sediment or bed material determined by sieve and sedimentation methods.

Particle-size classification agrees closel" with recommendations made by the American Geophysical Union Subcommittee on Sediment Terminolog" (Lane and others, 1947, p. 937). The classification is as follows:

Clay: Smaller than $0.004 \mathrm{~mm}$.

Silt: Between 0.004 and $0.062 \mathrm{~mm}$.

Sand: Between 0.062 and $2.0 \mathrm{~mm}$.

Gravel: Between 2.0 and $64.0 \mathrm{~mm}$.

The particle-size distributions given in this report are not necessarily representative of the particle sizes of sediment in transport in the natural stream. Most of the organic matter is removed, and the sample is subjected to mechanical and chemical disrorsion before analysis of the silt and clay.

Parts per million (ppm) for suspended sediment is computed as 1 million times the ratio of the weight of sediment to the weight of the mixture of water and sediment. 
Prediction limits are lines about the regression curves for a selected significance level within the range of previously experienced values. They are computed from the equation:

where

$$
\left.\begin{array}{l}
U \\
L
\end{array}\right\}= \pm t_{[(1+\gamma) / 2](n-2)} S p
$$

$t$ is a value from statistical " $t$ " distribution table (Dixon and Massey, 1957),

$\gamma$ is a selected confidence level (95 percent),

$S p$ is the standard error of prediction, and

$U$ and $L$ are the upper and lower prediction limits about the curve.

Runoff is that part of the precipitation that appears in surface streams.

Runoff in inches (in.) shows the depth to which the drainage area would be covered if all the runoff for a given time period were uniformly distributed.

Sediment is solid material that originates mostly from disintegrated rocks and is transported by, suspended in, or deposited from water; it includes chemical and biochemical precipitates and decomposed organic material such as humus. The quantity, characteristics, and cause of the occurrence of sediment in streams are influenced by environmental factors. Some major factors are: degree of slope, length of slope, soil characteristics, land usage, and quantity and intensity of precipitation.

Sediment discharge is the rate at which dry weight of sediment passes a section of a stream or is the quantity of sediment, as measured by dry weight, or by volume, that is discharged in a given time.

Sediment load is the total sediment being moved by the stream or the quantity of sediment that is transported in a given length of time.
Stage-discharge relation is the relation between gage height and the volume of water flowing ir a channel, expressed as volume per unit of time.

Standard error of estimate (Se) is a measure of the variation of points about the regression line. Lines drawn a vertical distance of one standard error of estimate above and below the line of regression will encompass about two-thirds of the defining points.

Standard error of prediction $(\boldsymbol{S p})$ is made up of three parts: the error of the mean, the error of the slope of the line, and the standard error of estimate. It is computed as

where

$$
S p=\operatorname{Se} \sqrt{1+\frac{1}{n}+\frac{(X-\bar{X})^{2}}{\Sigma x^{2}}}
$$

$S e$ is standard error of estimate, $n$ is number of items in the sample, $X$ is any single value,

$\bar{X}$ is the mean value for the period 1959-65, and $\Sigma x^{2}$ is the summation of the squared deviation of $X$ from $\bar{X}$ for the period 1959-65.

Suspended sediment is the sediment that $s$ t any given time is maintained in suspension by the upvard components of turbulent currents or that exists ir suspension as a colloid.

Tons per day is the quantity of a substance in solution or suspension that passes a stream section during a 24-hour period.

Water year is the 12-month period, October 1 through September 30. The water year is designated by the calendar year in which it ends and which includes 9 of the 12 months. Thus, the year ending September 30, 1959 , is called the 1959 water year. 



\title{
Streamflow, Sediment-Transport, and Water-Temperature Characteristics of Three Small Watersheds in the Alsea River Basin, Oregon
}

\author{
By D. D. Harris and R. C. Williams
}

\begin{abstract}
Data collected during the prelogging period 1959-65 indicate an average annual runoff for Needle Branch and Deer and Flynn Creeks of 74.2, 75.1, and 77.7 inches, respectively. The measured precipitation at Flynn Creek of 92.9 inches was 5 inches less than at either Needle Branch or Deer Creek. Unit flood runoff during the prelogging period was found to be lowest on Flynn Creek and highest on Needle Branch. On Needle Branch, there appear to be two distinct low-fiow patterns, one for a saturated and one for an unsaturated soil condition. The average annual sediment yield was highest on Flynn Creek, 321 tons per square mile, and lowest on Needle Branch, 166 tons per square mile. Maximum water temperatures were $62^{\circ} \mathrm{F}$ on Flynn Creek and $61^{\circ} \mathrm{F}$ on Needle Branch and Deer Creek.
\end{abstract}

\section{INTRODUCTION}

What are the effects of logging on the regimen of a stream? This question is of major concern to water users and water-resource managers in a heavily forested State like Oregon, where many of the watersheds are subject to logging in the future.

To investigate the effects of logging, three small watersheds in the Alsea River basin on the west slope of the Oregon Coast Range (fig. 1) were selected for study. This was an interdisciplinary investigation to evaluate the influence of specific logging methods on stream regimen and on aquatic resources. The study plan involved (1) clear-cut logging of one watershed, (2) stagger cutting (small, spaced clear cuts) of a second watershed, and (3) leav- ing a third watershed uncut as a control to evaluate changes in the logged watersheds. Data were to be collected on all thre? watersheds for a period of 7 years to define the prelogging calibration. The Oregon State University Department of Fisheries and Wildlife and the Oregon State Game Commission are studying the effects of logging on fish habitat, particularly in relation to salmon spawning. The School of Forestry at Oregon State University is evaluating in detail the effects of lorging in small drainage basins within the two logged watersheds, Deer Creek and Needle Branch. The U.S. Geological Survey was to study the integrated effects of logging on the De?r Creek and Needle Branch watersheds. Other participants in the study are the U.S. Forest Service, U.S. Soil Conservation Service, and GeorgiaPacific Corporation.

The purpose of this report is to define the hydrologic characteristics of the three principal study basins and to show the interrelations of these characteristics for the calibration period, water years 1959-65. The relations ceveloped for both Needle Branch and Deer.Crsek with respect to Flynn Creek will be used later during the treatment and recovery phases to dotermine the effects of logging. This report ircludes a discussion of streamflow, sediment transport, and water temperature of the three streams, and precipitation on the three watersheds. 


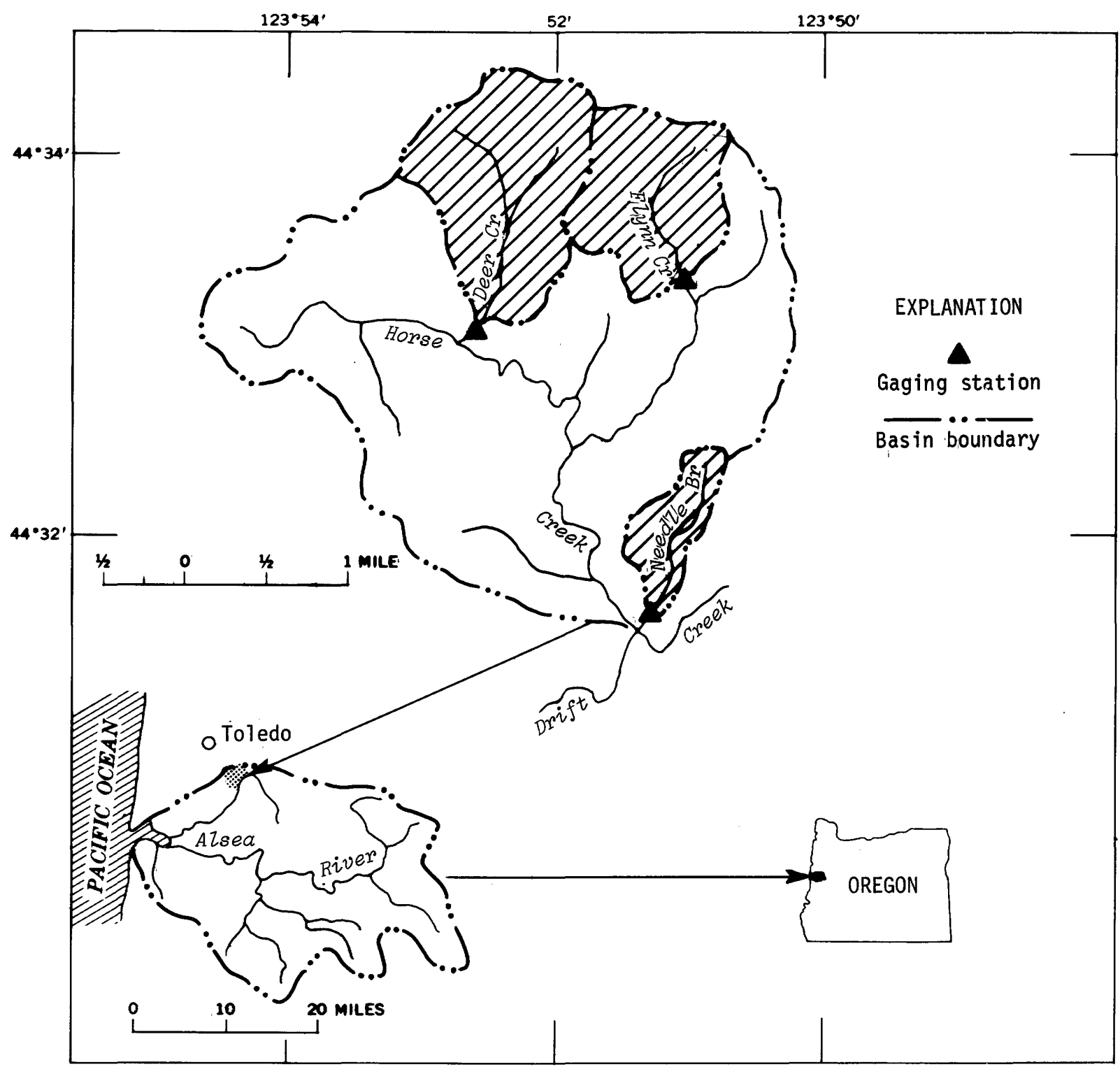

FIGURE 1.-Location of study watersheds in Alsea River basin.

\section{HYDROLOGIC ENVIRONMENT}

All three streams in the study area flow in a southerly direction, and the basins lie in the path of the prevailing westerly winds from the Pacific Ocean. Altitudes range from 440 feet at the Needle Branch gaging station to 1,600 feet at the highest point of the Deer Creek basin. The valleys are V-shaped and cut into the Tyee Sandstone of Tertiary age. The basins are characterized by a heavy canopy of Douglas-fir mixed with alder and are almost completely covered by a heavy growth of understory vegetation that provides goot protection against erosion and soil-moisture loss by evaporation.

Deer Creek basin has a drainage area of $\mathbf{1 . 1 7}$ square miles. Sidehill slopes average about 40 percent and are characteristically covered by a thin mantle of stony soil. Basin altitudes range from 600 to 1,600 feet. The overstiry is about 60 percent Douglas-fir and 40 percent alder, and 
the understory is mainly of salmonberry and sword fern.

Flynn Creek basin has a drainage area of 0.78 square mile. Sidehill slopes average about 34 percent and altitudes range from 680 to 1,400 feet. Much of the basin is on a moderate dip slope of sandstone beds generally overlain by a thick layer of sandy soil. Overstory is about 70 percent alder and 30 percent Douglas-fir, and the understory is similar to that of Deer Creek.

Needle Branch basin has a drainage area of 0.27 square mile. Sidehill slopes average about 37 percent and are largely covered with shallow stony soil. Basin altitudes range from 440 to 1,200 feet. The overstory is about 85 percent Douglas-fir and 15 percent alder, and vine maple is the principal understory plant. Thirty-two acres in the headwaters of Needle Branch was logged in the early 1950's.

The mild, humid climate of the area is typical of the coastal region of western Oregon. More than 90 inches of precipitation occurs annually, most of it from October to May. Temperatures generally range between $20^{\circ} \mathrm{F}$ and $90^{\circ} \mathrm{F}$, with a mean of about $51^{\circ} \mathrm{F}$.

\section{DATA COLLECTED AND METHODS USED}

Measurements of precipitation, streamflow, sediment transport, and water temperature near the mouths of the three study streams provided the data needed to develop relations between basin hydrologic characteristics.

\section{PRECIPITATION}

Precipitation data were collected at weighingtype rain gages just downstream from each of the outflow stream-gaging stations. Because the gages are at the lowest altitude in each basin, the records undoubtedly do not indicate the average precipitation on the basins. Although the records probably indicate less than the basin average and are partly estimated, they are considered adequate to indicate approximate areal distribution and year-to-year variation of precipitation.

\section{STREAMFLOW}

Records of runoff for the three study basins were collected at standard U.S. Geological Sur- vey gaging stations. Stage records were obtained on continuous analog recordors. The recorders are housed in 4- by 4 -foot, shelters over 42-inch culvert-pipe stilling wells, each of which is connected to the stream by t'vo 2-inch intake pipes. The stage-control strusture for each station is a concrete V-notch weir.

Discharges at the gaging stations were determined from stage-discharge relations defined by a series of discharge measuremerts. Highand medium-flow discharge measurements were made using either the standard Price or pygmy current meter; low-flow measurements were made volumetrically. On Flynn $\varepsilon$.nd Deer Creeks, volumetric measurements were made by timing the filling of a concrete box located immediately downstream from the weirs; on Needle Branch they were made by timing the filling of a metal container of know'n volume held below the weir. Each discharge measurement was plotted to the concurrent gage height. Stage-discharge relations were developed from the measurements for each site and were used to obtain the discharge data for the analyses.

\section{SEDIMENT TRANSPORT}

For the calibration period, the sediment load at the sampling sites near the mouths of the three principal streams can be divided into three classifications: (1) That computed from data obtained with a U.S. DH-48 sedimert sampler at the sampling stations, (2) that which remained deposited in the weir pools because of backwater created by the weirs, and (3) that composed of coarse mineral and organic matter too large to be sampled with a U.S. DH-48 sampler.

The major part of the load was sampled at the three sites and computed by methods outlined in the U.S. Geological Survay watersupply paper series "Quality of Surfe ce Waters of the United States" and in the reports of the U.S. Inter-Agency Committee on Nater Resources $(1957 \mathrm{a}, 1957 \mathrm{~b}, 1959,1961,1963)$. During the 1959-61 water years, the suspendedsediment load was sampled with U.S. DH-48 samplers at footbridges several hundred feet upstream from the gaging stations. Beginning with the 1962 water year, sampling was done 
on the concrete control weirs. In the sampling process, the nozzle of the U.S. DH-48 sampler traversed the entire depth of the stream-from water surface to the crest of the weir. Some particles that normally travel as bedload were caught by the samplers. However, in this report the sediment concentration and load obtained from sediment samples are termed "suspended sediment" to differentiate from the sediment load computed by adding an increment for the sediment retained just upstream from the weirs where sampling was done. To obtain equivalent records for the entire calibration period, adjustments were made to the suspended-sedimentload records for the 1959-61 water years, on the basis of comparison samples obtained at the two sites on each stream during the 1961 water year.

The part of the sediment load trapped in the weir pools was determined by cross-section surveys at the end of each water year, beginning in 1962. The volume of fill, or scour, was computed by the method of average-end areas. Two samples of the deposit were analyzed for particle-size distribution, and the specific weight was determined. Volume of the deposit was converted to weight for direct combination with the suspended-sediment load. The load represented by sediment in the deposits is probably not directly related to the suspendedsediment load. However, these streams have the competence to move substantial amounts of coarse sediment only during the highflow period when essentially all the suspended sediment is transported. Therefore, for the purpose of this study the deposited sediment was prorated by the year and by the month on the basis of the suspended-sediment load.

The part of the coarse sediment load that was neither sampled nor trapped in the weir pools cannot be accurately determined. During 1965, samples were obtained using a 1/4-inch wire-mesh basket (in the shape of the weir notch) placed in the weir notch for selected periods. The unsampled loads at the sampling stations were approximated from the amount of material trapped during a specific period of time. Although this method did not provide an accurate determination, it did provide data to appraise the importance of the unsampled load. It was found that the streams transported coarse mineral and organic material only during periods when suspended-sediment loads were very high. Because the amounts defected were a very small percentage of the total sediment loads at those times, the unsampled loads probably represented only a small percentage of the annual load. The relations of the se liment yield of Deer Creek and Needle Branch watersheds to that of Flynn Creek watershed probably are not materially in error by using this method of approximating the coarse unsampled load.

Methods used for particle-size analysis are outlined in reports of the U.S. Inter-Agency Committee on Water Resources (1957a, 1957b, $1959,1961,1963)$. To approximate the organic fraction of the suspended-sediment load, organic materials were separated from the mineral sediments, dried, and weighed.

\section{WATER TEMPERATURES}

The daily maximum and minimum water temperatures used in subsequent parts of this report were determined by use of thermograph attachments on the water-stage recorders, which provided continuous records for each stream.

\section{ANALYSIS AND INTERPRETATION OF DATA}

The analysis of data was intended to define the hydrologic characteristics of the prelogging period $_{i}$ for future comparison with those of the postlogging period. The methods of analysis used are patterned after standard correlation methods (Ezekiel and Fox, 195?) and are similar to those previously used br Schneider and Ayer (1961) and by Richardson (1965) to determine changes in the hydrologic characteristics caused by changes in vegetative cover. The principal method was to relate streamflow, sediment transport, and water temjeratures of Needle Branch and Deer Creek to those of the control stream, Flynn Creek. Regression lines of the relations and their equations were developed. From these equations, values of dependent variables (Needle Branch and Deer Creek) can be estimated from values of the independent variable (Flynn Creek). 
Prediction limits at the 95-percent level were computed for the regressions to determine the significance of future changes of individual values. The 95-percent prediction limits are shown for all relations. If future individual values plot outside the prediction limits shown, the change resulting from logging will be considered significant.

Comparison of prelogging with postlogging conditions by covariance analysis should provide a better method of measuring the significance of future changes in relations than would the use of the standard error of prediction; however, because covariance analysis requires both prelogging and postlogging data, it is not further considered in this prelogging report.

\section{PRECIPITATION}

To isolate the effects of logging on streamflow, sediment transport, and water temperature, using relations of Needle Branch and of Deer Creek with Flynn Creek, the areal distribution of precipitation must be reasonably consistent over the three-basin study area. Therefore, for later comparison with precipitation data for the postlogging period, it was important to study the areal distribution that occurred during the 7-year calibration period.

Annual precipitation at the three rain gages is shown in table 1 . The annual average precipitation at Needle Branch and at Deer Creek exceeded that at Flynn Creek by more than 4.5 inches. In 1959 precipitation at the Needle Branch gage was more than 12 inches greater than at the Flynn Creek gage; in 1965 precipitation at the Needle Branch gage was nearly 2 inches less than at Flynn Creek gage.

The relations between cumulative precipitation for Needle Branch and Flynn Creek and for Deer Creek and Flynn Creek are shown in figure 2 . The relations were fairly consistent throughout the study period, although the one for Needle Branch shows progressively less excess precipitation in relation to Flynn Creek. The indicated change on Needle Branch is assumed to be of a temporary nature, but the assumption will be investigated further during the postlogging period.
TABLE 1.-Annual precipitation, in inches, measured at the precipitation gages, and difference? from that measured at the Flynn Creek gage

\begin{tabular}{|c|c|c|c|c|c|}
\hline \multirow[b]{2}{*}{$\begin{array}{l}\text { Water } \\
\text { year }\end{array}$} & \multirow[b]{2}{*}{$\begin{array}{c}\text { Flynn } \\
\text { Creek } \\
\text { precipi- } \\
\text { tation }\end{array}$} & \multicolumn{2}{|c|}{ Needle Branch } & \multicolumn{2}{|c|}{ Deer Creek } \\
\hline & & $\begin{array}{c}\text { Precipi- } \\
\text { tation }\end{array}$ & $\begin{array}{l}\text { Difference } \\
\quad \text { from } \\
\text { Flynn Creek }\end{array}$ & $\underset{\text { Precipi- }}{\text { tation }}$ & $\begin{array}{l}\text { Difference } \\
\text { from } \\
\text { Flynn Creek }\end{array}$ \\
\hline $\begin{array}{l}1959 \\
1960 \\
1961 \\
1962 \\
1963 \\
1964 \\
1965\end{array}$ & $\begin{array}{r}103.70 \\
82.29 \\
105.86 \\
85.68 \\
83.59 \\
95.34 \\
94.09\end{array}$ & $\begin{array}{r}115.76 \\
91.81 \\
109.84 \\
90.54 \\
87.52 \\
96.63 \\
92.30\end{array}$ & $\begin{array}{r}+12.06 \\
+9.52 \\
+3.98 \\
+4.86 \\
+3.93 \\
+1.29 \\
+1.79\end{array}$ & $\begin{array}{r}109.00 \\
88.34 \\
111.29 \\
88.52 \\
88.05 \\
99.02 \\
98.24\end{array}$ & $\begin{array}{r}+5.30 \\
+6.05 \\
+5.43 \\
+2.84 \\
+4.46 \\
+3.68 \\
+4.15\end{array}$ \\
\hline Mean_ & 92.93 & 97.77 & +4.84 & 97.49 & +4.56 \\
\hline
\end{tabular}

Extension of the cumulative procipitation relations after logging will help to indicate if a future change in a streamflow relation was the result of logging alone.

\section{STREAMFLOW}

In deciding which streamflow relations should be defined for the calibration period, consideration was given to the changes that could be expected as a result of logging. Logring could result in changing (1) the timing, a real distribution, and volume of runoff, (2) the magnitude of high flows and flood peaks, and (3) the magnitude and duration of summer low flows.

Distribution and Volume of Runoff

Annual runoff from the three study basins for water years 1959-65 is shown in table 2, and the daily mean discharges are Fiblished in annual reports of the U.S. Geolog:nal Survey (1960, 1961, 1961-64, 1966c).

Flow-duration curves developed for the three study streams (fig. 3) show the flow characteristics throughout the range of discharge, in cubic feet per second per square mile, without

TABLE 2.-Annual runoff, in inches, for each year of the calibration period

\begin{tabular}{|c|c|c|c|}
\hline $\begin{array}{l}\text { Water } \\
\text { year }\end{array}$ & $\begin{array}{l}\text { Flynn } \\
\text { Creek }\end{array}$ & $\begin{array}{l}\text { Needis } \\
\text { Branch }\end{array}$ & $\begin{array}{c}\text { Deer } \\
\text { Creek }\end{array}$ \\
\hline 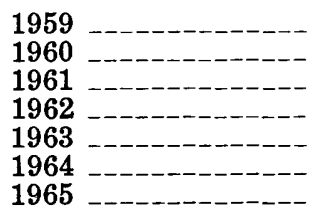 & $\begin{array}{l}78.60 \\
72.18 \\
93.30 \\
66.45 \\
69.17 \\
77.21 \\
87.07\end{array}$ & $\begin{array}{l}84.04 \\
69.55 \\
85.56 \\
61.61 \\
62.83 \\
75.28 \\
80.80\end{array}$ & $\begin{array}{l}78.63 \\
67.81 \\
\mathbf{8 9 . 6 4} \\
64.27 \\
64.68 \\
74.90 \\
\mathbf{8 5 . 4 7}\end{array}$ \\
\hline Mean & 77.71 & 74.24 & 75.06 \\
\hline
\end{tabular}



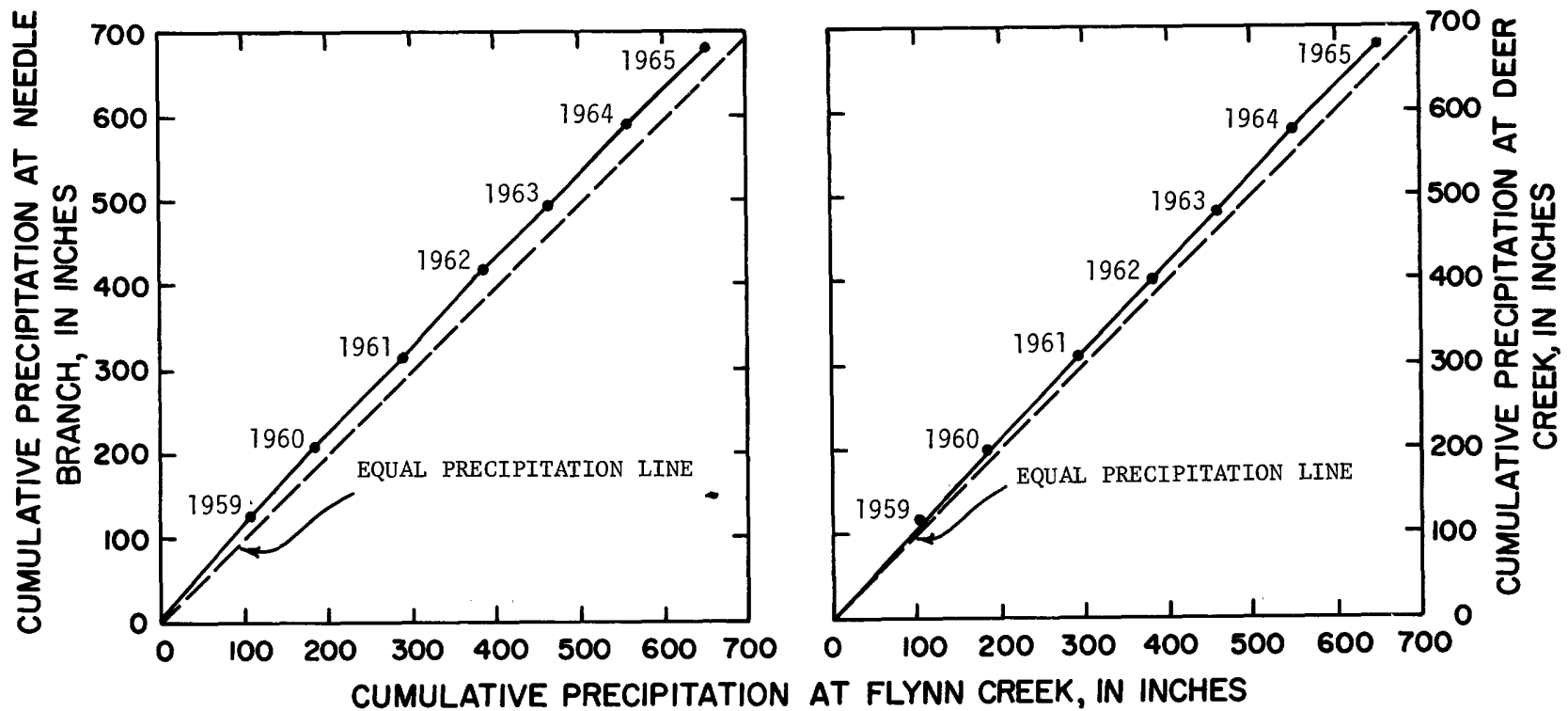

Figure 2.-Relation of annual precipitation at Needle Branch and at Deer Creek gages to that at the Flynn Creek gage.

regard to the sequence of occurrence. The curves cannot be used for precise future evaluation of changes in flow characteristics. However, for a general comparison of the three streams, the curves are used to show the average percentage of time that specified discharges were equaled or exceeded. The curves merge above $10 \mathrm{cfs}$ per sq mi, indicating similar high-flow characteristics in the three basins. However, low-flow characteristics differ. For example, a discharge of $0.3 \mathrm{cfs}$ per sq $\mathrm{mi}$ is equaled or exceeded 96 percent of the time on Deer Creek, 93 percent of the time on Flynn Creek, and 83 percent of the time on Needle Branch.

The range and seasonal distribution of flows for Needle Branch and Deer Creek for the prelogging period are shown by the maximumminimum hydrographs in figure 4 . The hydrographs, which will provide a basis for visual comparison with the patterns of the study streams after logging, were developed by using the maximum and minimum daily discharges in the 7-year calibration period.

The volume of runoff from a basin depends on precipitation, effects of changes in groundwater storage, and evapotranspiration. No ground-water data are available for this study; however, because ground-water storage at the beginning of each water year seems to be small, the change from year to year is ass negligible. By assuming negligible change in ground-water storage, the differenc? between precipitation and runoff is evapotranspiration. Although precipitation at the gages is not considered to be a reliable measure of precipitation on the basin, the difference betw'een measured precipitation and runoff should approximate the minimum evapotranspiration. Minimum annual evapotranspiration estimated by this method (precipitation data from table 1 minus runoff data from table 2) shows $\mathbf{1 5 . 2 2}$ inches at Flynn Creek, 23.53 inches at Needle Branch, and 22.43 inches at Deer Creek-an average of 20.39 inches for the thro basins. Average annual lake evaporation for this area, as determined by the U.S. Weather Bureau from evaporation pan data (Kohler and others, 1959), is about 22.5 inches. On the basis of these data, evapotranspiration is estimated to be 21 inches.

Logging normally tends to redure evapotranspiration initially and thereby increases the runoff. Theoretically, if evapotranspiration were entirely eliminated, Needle Branch runoff would be increased by 21 inches annually. Runoff for Deer Creek, where 25 percent of the basin will be clear cut, would be increased by 


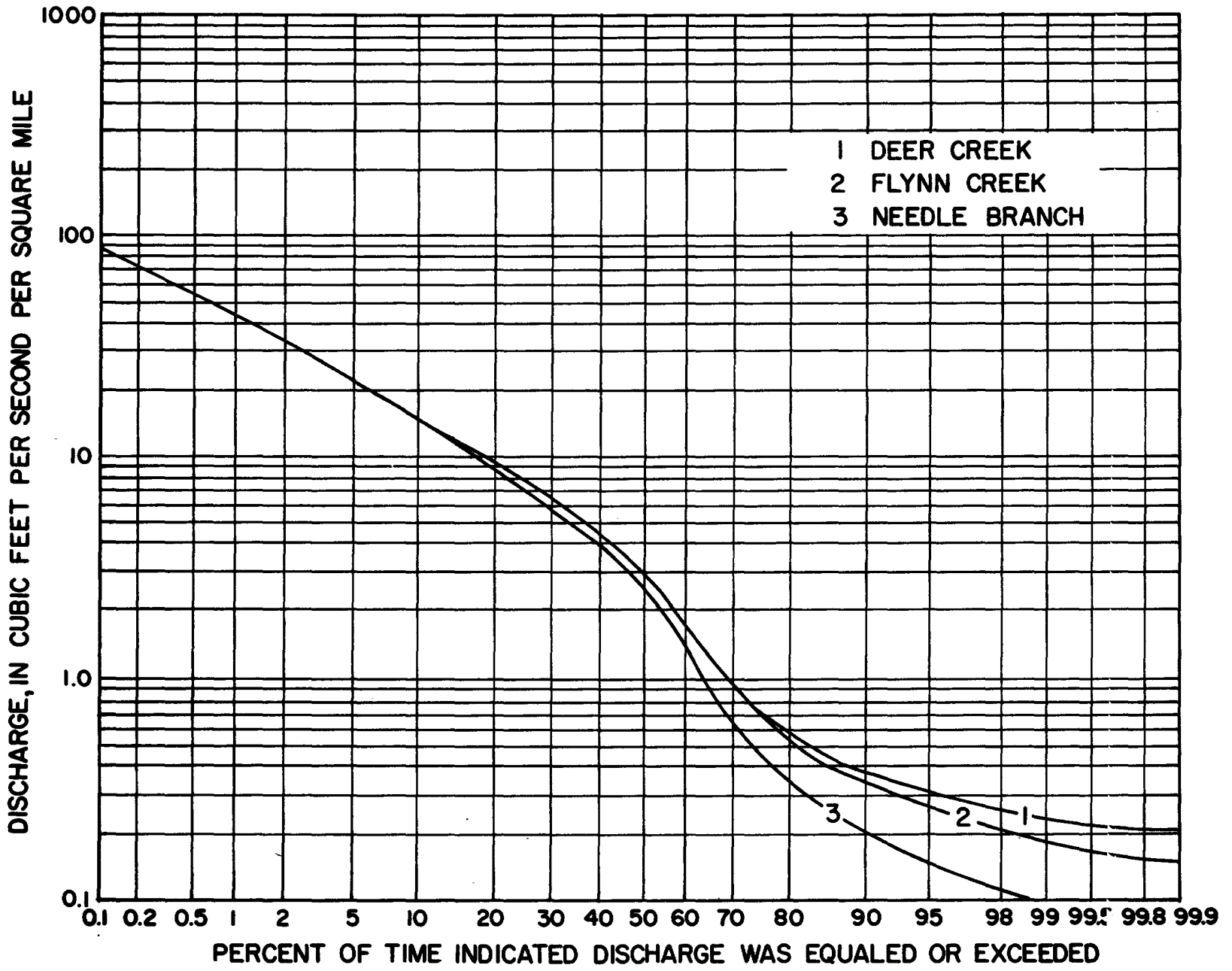

Figure 3.-Duration curves of discharge for the three study streams (based on records for water years 1959-65).

5.2 inches, or 25 percent of 21 inches. It is improbable that such a drastic increase in runoff would. actually occur, but the figures show the maximum potential increase.

Annual runoff for Needle Branch and for Deer Creek were related to that of Flynn Creek by regression analyses (fig. 5). The relations were well defined by the annual values except for those of 1959 at Needle Branch. In 1959, the runoff at Needle Branch was 5 inches more than that at Flynn Creek, whereas in subsequent years runoff was always greater at Flynn Creek. Apparently, the difference was caused by a change in the areal distribution of precipitation, as indicated by the excess of 12 inches of precipitation measured at Needle Branch over that at Flynn Creek in 1959. This compared with an average excess precipitation of 3.63 inches in subsequent years. During 1959-65, runoff from Flynn Creek progres rively decreased in proportion to precipitation measured at the rain gage. This proportional decrease could have been caused by a change in the areal distribution of precipitation; however, because there was only one precipitation ge.ge in the Flynn Creek basin and because of t $\mathrm{t}$ ? reduced accuracy of the partly estimated pracipitation values, no further analysis was $m \varepsilon$ de of the precipitation-runoff relations.

Regressions of seasonal runoff were developed for future evaluation of changes (fig. 6). The period November-February was selected as the 


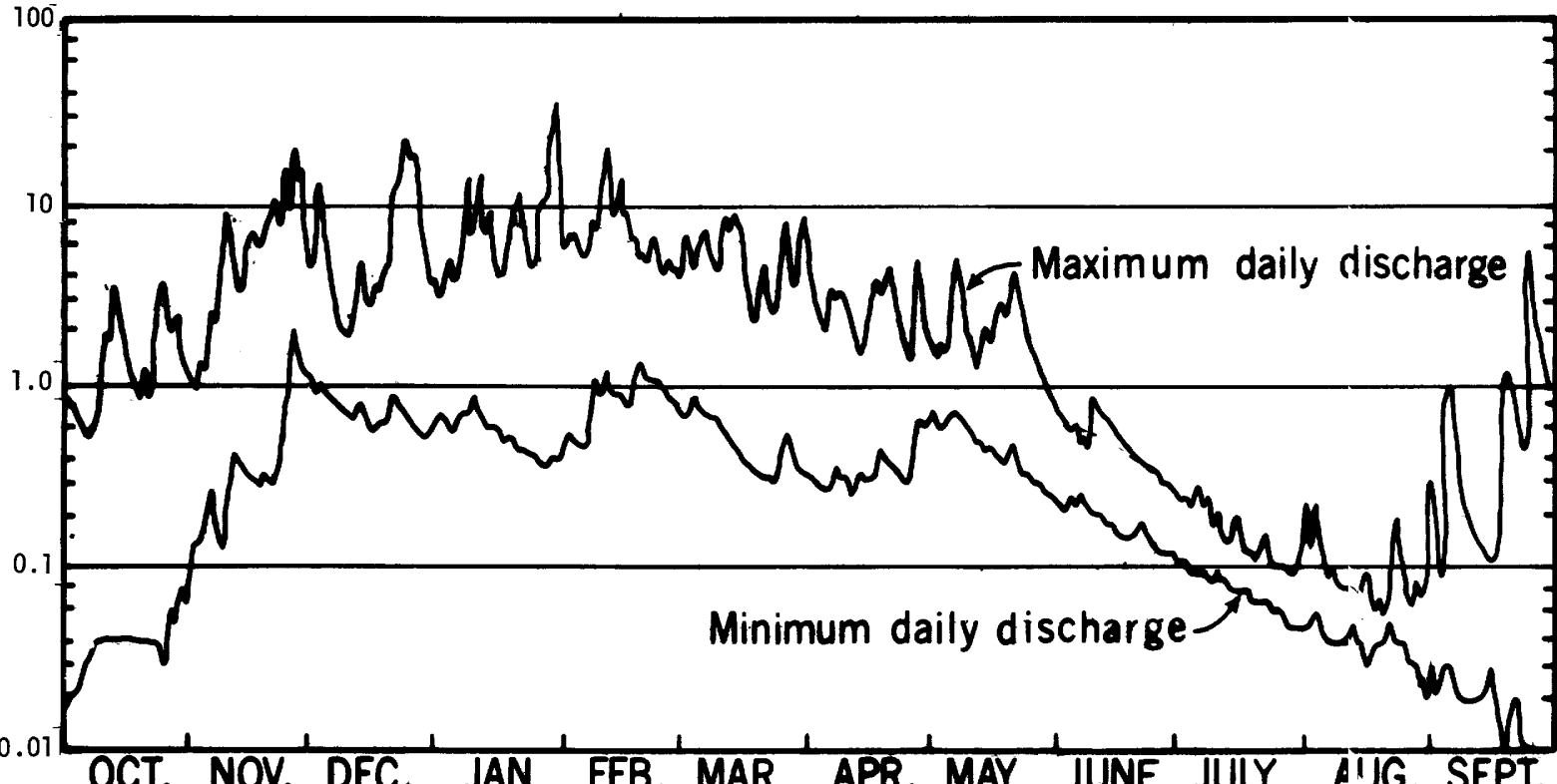

NEEDLE BRANCH MAXIMUM-MINIMUM HYDROGRAPH 1959-19:5

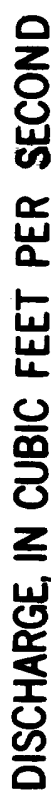

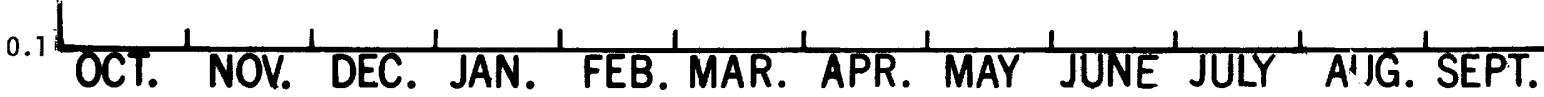
DEER CREEK MAXIMUM-MINIMUM HYDROGRAPH 1959-1965

FIGURE 4.-Range and seasonal distribution of flows for Needle Branch and Deer Creek. 


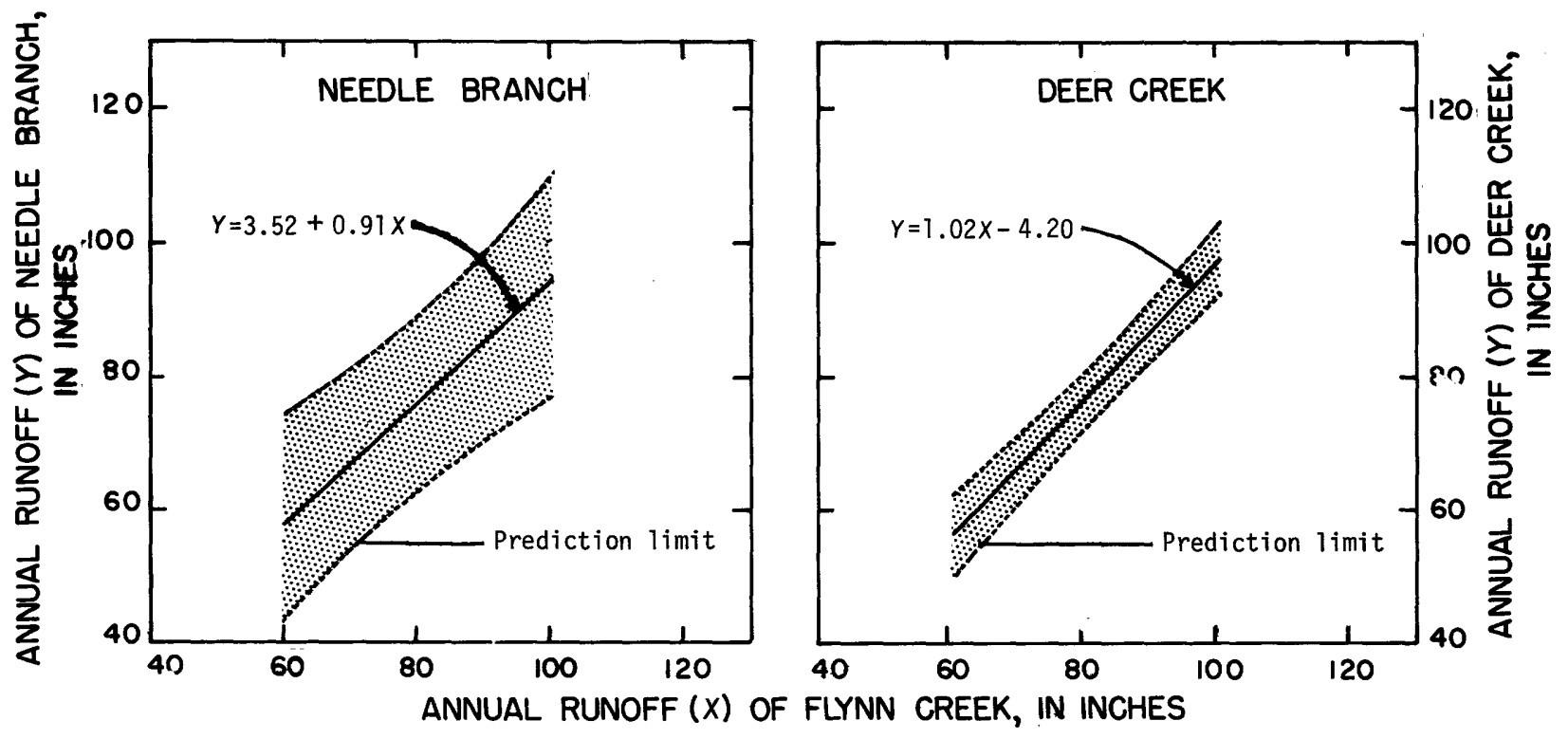

Figure 5.-Relation of annual runoff of Needle Branch and of Deer Creek to that of Flynn Creek for water years 1959-65.

dormant and rainy season, March-June as the growing and high-flow season, and July-October as the high-evapotranspiration and low-flow season.

High Flow

Regressions of peak discharges were devel-

更

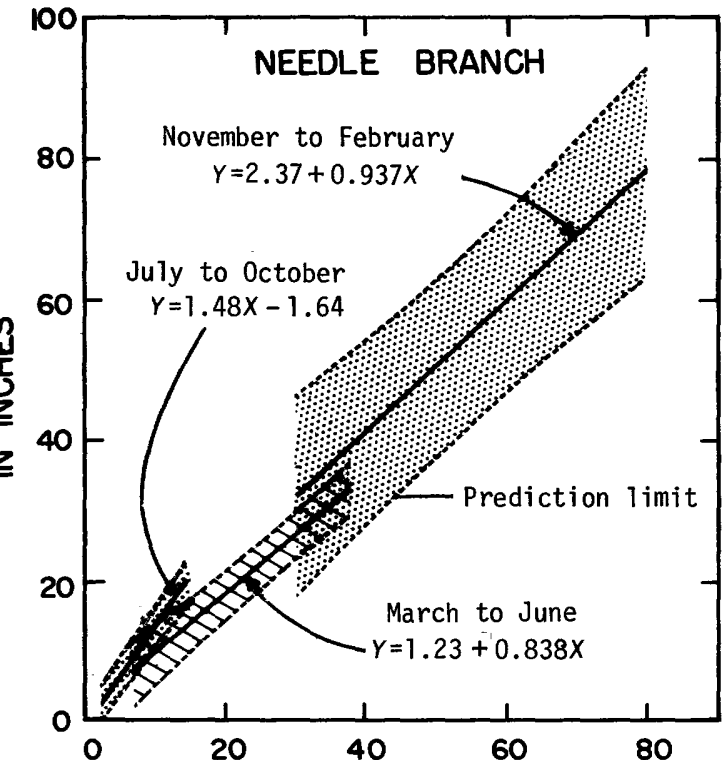

oped to establish the high-flow relations of the three basins prior to logging. All peaks of 50 cfs per sq mi or greater on Flynn C:eek and concurrent peaks for Needle Branch and Deer Creek were used in the regressions and are listed in table 3 . The regressions of peak flows

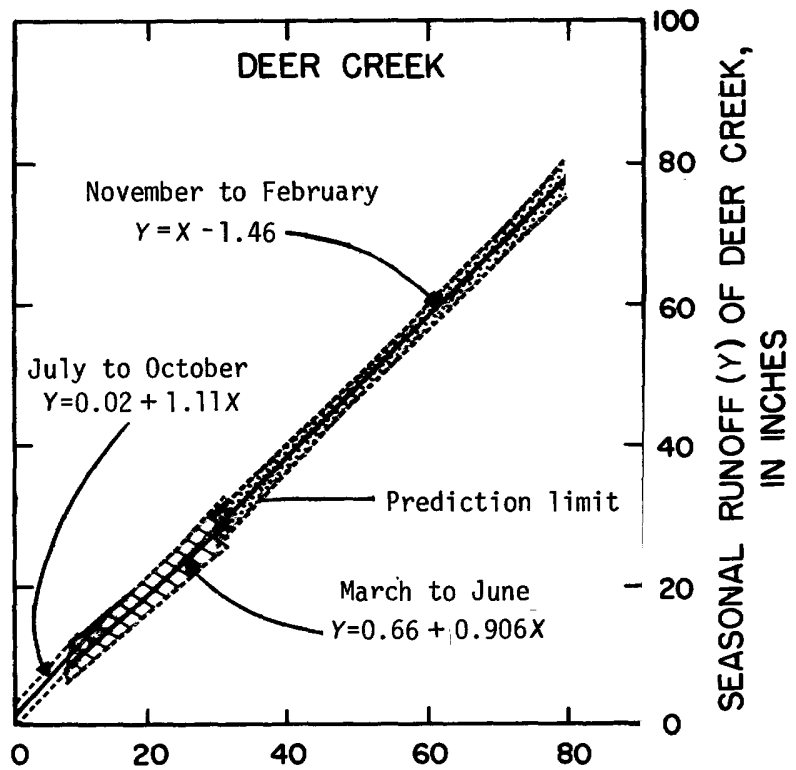

SEASONAL RUNOFF $(x)$ OF FLYNN CREEK, IN INCHES

Figure 6.-Relation of seasonal runoff of Needle Branch and of Deer Creek to that of Flynn Creek for water years 1959-65. 
TABLE 3.-Peak discharge and runoff for all peaks greater than 50 cfs per sq mi on Flynn Creek and concurrent peaks on Needle Branch and Deer Creek

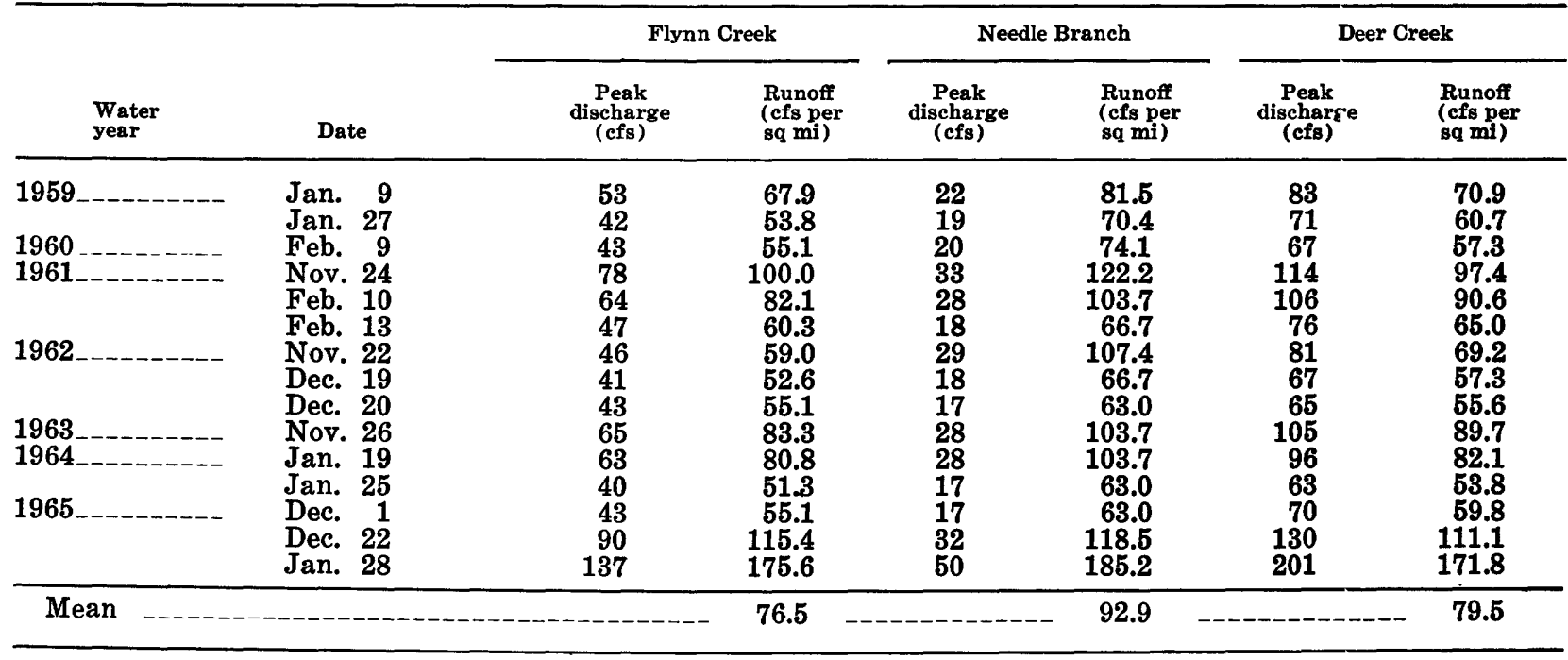

of Needle Branch and of Deer Creek with Flynn Creek and prediction limits are shown in figure 7.

Three-day runoff totals for storm periods on Needle Branch and Deer Creek were correlated with concurrent totals for Flynn Creek (fig. 8). These totals, shown in table 4 , are a measure of high-flow runoff volumes. Theoretically, in a statistical appraisal, independent samples of the 3-day flood volumes should be used. However, four of the 25 periods usec' were only 1 day apart and may not represent completely independent events of runoff; but. because the major parts of the runoff were from entirely separate storms, the periods were used and are assumed to be independent. Tro frequently used unit-hydrograph method for determining runoff volumes was not used because precipita-
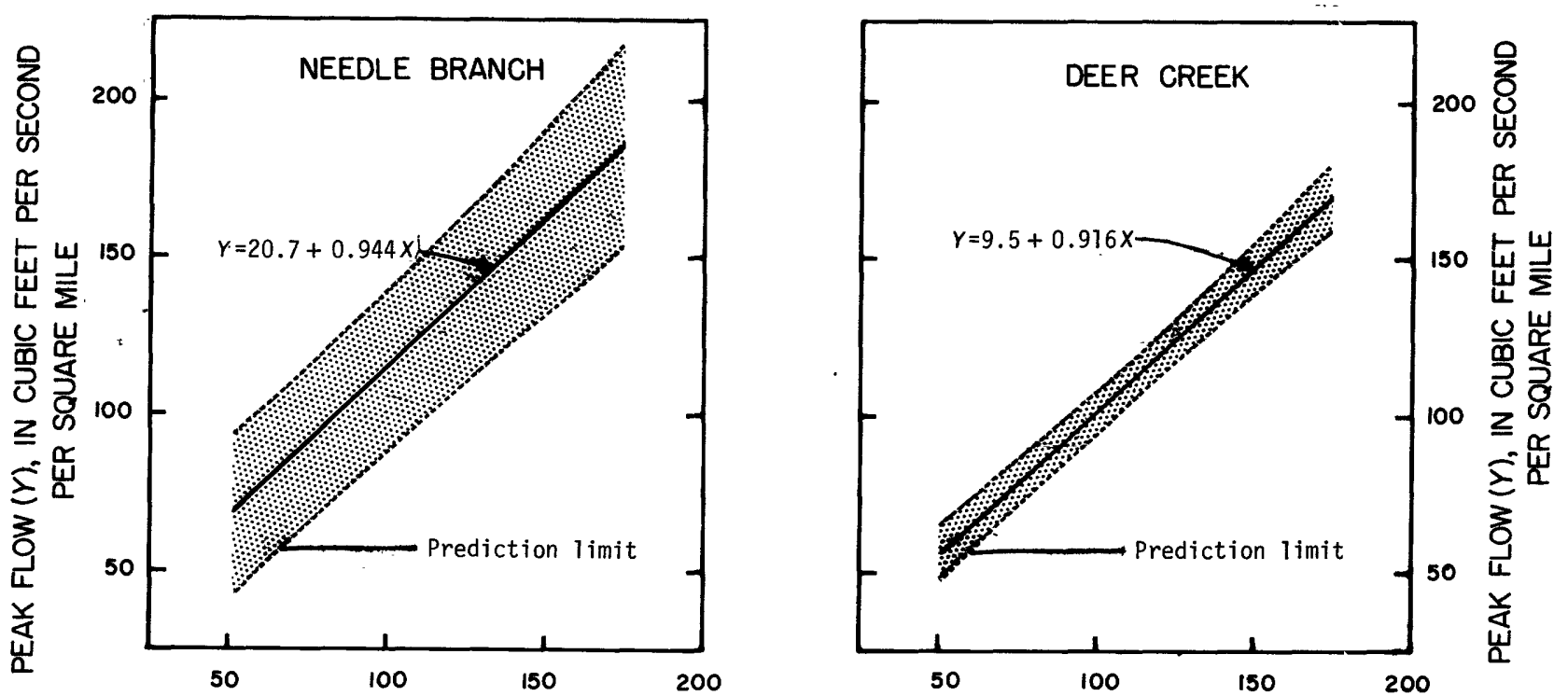

FLYNN CREEK PEAK FLOW $(X)$, IN CUBIC FEET PER SECOND PER SQUARE MILE

Figure 7.-Relation of peak flow of Needle Branch and of Deer Creek to that of Flynn Creek for water years 1959-65. 
TABLE 4.-Three-day high-flow runoff for Flynn Creek, Needle Branch, and Deer Creek

\begin{tabular}{|c|c|c|c|c|}
\hline \multirow[b]{2}{*}{$\begin{array}{l}\text { Water } \\
\text { year }\end{array}$} & \multirow{2}{*}{$\begin{array}{c}\text { Period } \\
\text { of } \\
\text { high flow }\end{array}$} & \multicolumn{3}{|c|}{ Runoff, in inches } \\
\hline & & $\begin{array}{l}\text { Flynn } \\
\text { Creek }\end{array}$ & $\begin{array}{l}\text { Needle } \\
\text { Branch }\end{array}$ & $\begin{array}{l}\text { Deer } \\
\text { Creek }\end{array}$ \\
\hline 1959 & 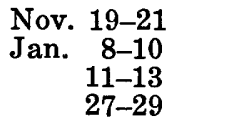 & $\begin{array}{l}3.58 \\
4.86 \\
3.19 \\
3.86\end{array}$ & $\begin{array}{l}4.19 \\
5.36 \\
3.39 \\
4.41\end{array}$ & $\begin{array}{l}3.94 \\
4.70 \\
2.92 \\
4.16\end{array}$ \\
\hline $1960 \ldots$ & $\begin{array}{ll}\text { Feb. } & 6-8 \\
9-11 \\
15-17\end{array}$ & $\begin{array}{l}3.39 \\
4.48 \\
2.19\end{array}$ & $\begin{array}{l}3.07 \\
4.75 \\
1.86\end{array}$ & $\begin{array}{l}3.56 \\
4.32 \\
2.03\end{array}$ \\
\hline $1961_{------}$ & $\begin{array}{l}\text { Nov. } 23-25 \\
\text { Feb. } 10-12 \\
13-15 \\
\text { Mar. } 13-15\end{array}$ & $\begin{array}{l}5.82 \\
6.06 \\
5.01 \\
3.48\end{array}$ & $\begin{array}{l}6.29 \\
6.27 \\
4.59 \\
\mathbf{3 . 3 1}\end{array}$ & $\begin{array}{l}5.69 \\
5.97 \\
4.93 \\
3.94\end{array}$ \\
\hline $1962_{-----}$ & $\begin{array}{l}\text { Nov. } 22-24 \\
\text { Dec. } 19-21 \\
\text { Mar. } 25-27\end{array}$ & $\begin{array}{l}2.67 \\
4.82 \\
3.67\end{array}$ & $\begin{array}{l}3.87 \\
5.23 \\
3.11\end{array}$ & $\begin{array}{l}2.96 \\
4.99 \\
3.56\end{array}$ \\
\hline $1963_{-----}$ & $\begin{array}{l}\text { Nov. } 25-27 \\
\text { Feb. } 2-4 \\
\text { Mar. } 30-A \text { pr. } 1\end{array}$ & $\begin{array}{l}5.24 \\
2.91 \\
2.77\end{array}$ & $\begin{array}{l}5.62 \\
2.67 \\
2.80\end{array}$ & $\begin{array}{l}5.02 \\
2.64 \\
2.26\end{array}$ \\
\hline 1964 & $\begin{array}{cc}\text { Jan. } & 6-8 \\
19-21 \\
24-26 \\
\text { Mar. } 11-13\end{array}$ & $\begin{array}{l}3.34 \\
4.91 \\
4.48 \\
2.53\end{array}$ & $\begin{array}{l}3.84 \\
5.21 \\
4.41 \\
\mathbf{3 . 0 7}\end{array}$ & $\begin{array}{l}3.27 \\
4.74 \\
4.70 \\
2.45\end{array}$ \\
\hline 1965 & $\begin{array}{l}\text { Nov. } 30-\text { Dec. } 2 \\
\text { Dec. } 22-24 \\
25-27 \\
\text { Jan. } 27-29\end{array}$ & $\begin{array}{r}4.24 \\
9.11 \\
4.77 \\
11.11\end{array}$ & $\begin{array}{r}4.53 \\
9.50 \\
4.42 \\
11.71\end{array}$ & $\begin{array}{r}4.35 \\
8.68 \\
4.80 \\
11.82\end{array}$ \\
\hline Mean _- & . & 4.50 & 4.70 & 4.50 \\
\hline
\end{tabular}

tion and runoff data were not adequately synchronized.

Maximum deviations from the relation curves were 1.07 inches for Needle Branch ard 0.58 inch for Deer Creek. On Needle Branch, the 3 -day runoff volumes ranged from 1.86 to 11.71 inches and averaged 4.70 inches. On Deer Creek, the 3-day runoff volumes ranged from 2.03 to 11.82 inches and averaged 4.50 inches.

The Needle Branch-Flynn Creek flocd-peak relation is much more erratic than the Deer Creek-Flynn Creek relation, whereas the 3-day high-flow runoff relations for these streams are consistent and well defined. Peak runoff is lower on Flynn Creek than on either Needle Branch or Deer Creek, whereas 3-day runoff volumes are about the same on Deer and Flynn Creeks and highest on Needle Branch.

\section{Low Flow}

The hydrographs in figure 4 show th ' $t$ the recession from the winter and spring high flows generally begins in late spring and ends in September or October. The time and vol'ime of flow at the beginning of the recession are major factors in determining the low-flow rate in late

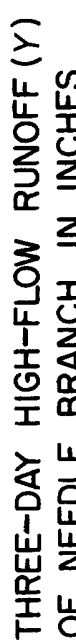

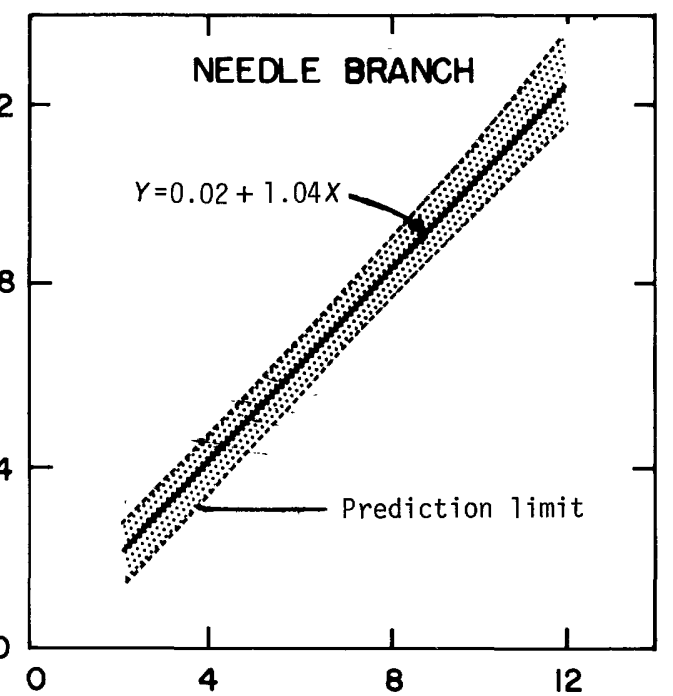
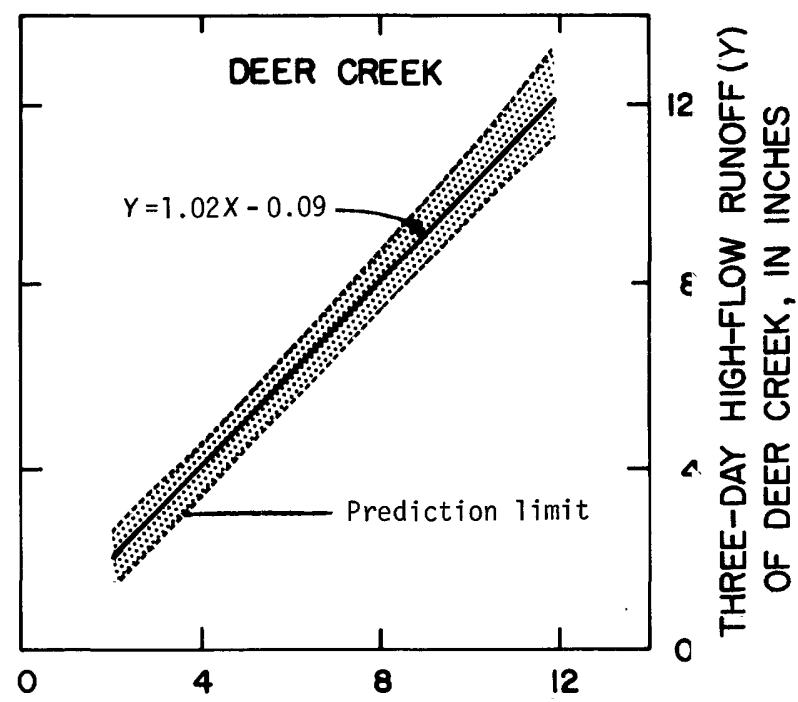

THREE-DAY HIGH-FLOW RUNOFF $(X)$ OF FLYNN CREEK, IN INCHES

FIGURE 8.-Relation of 3-day high-flow runotf total of Needle Branch and of Deer Creek to that of Flynn Creek for water years 1959-65. 
summer and early fall. The recession rate is controlled principally by the permeability of the soils, by the geology, and by evapotranspiration. Therefore, a change in evapotranspiration caused by removal of vegetation and a disruption of the soils could change the low-flow pattern.

Recession equations were developed by relating $Q_{0}$, the discharge at some instant, to $Q_{t}$, the discharge $t$ days later, for both Needle Branch and Deer Creek (fig. 9). A time interval, $t$, of 5 days was used, and only dry periods were selected for the analysis. Recession coefficients, the recession rates, determined from the regressions were 0.711 for Needle Branch and 0.879 for Deer Creek.

Low-flow regressions were developed for Needle Branch and Flynn Creek and for Deer Creek and Flynn Creek to define the relations existing prior to logging (fig. 10). In the regressions, mean daily flows were used up to an equivalent of $2.5 \mathrm{cfs}$ per sq $\mathrm{mi}$, which amounts to $0.7 \mathrm{cfs}$ on Needle Branch, $3.0 \mathrm{cfs}$ on Deer Creek, and $2.0 \mathrm{cfs}$ on Flynn Creek. In comparison, the lowest flows recorded were $0.01,0.22$, and $0.13 \mathrm{cfs}$ on Needle Branch, Deer Creek, and Flynn Creek, respectively.
On Needle Branch there apjear to be two distinct low-flow relations. One relation is for periods when the soil mantle of the basin is saturated after heavy rains, and another relation is for periods when the soil has not reached saturation. Saturated condition " usually occur after a rain of about 2 inches ard are indicated when the stream rises as a result of a light rain during the recession period. Unsaturated conditions are indicated when ther' is no stream rise as a result of light to medium rains during the recession period. In Deer and Flynn Creek basins, the soil mantle apparently stays saturated longer and the streams rise after even a slight rain during the recession period.

As a result of logging, the greatest changes in recession rates and low flor's undoubtedly will occur in the year immediately following logging, and they should diminish in subsequent years. For this reason, the postlogging analysis should include an evaluation of (1) the abrupt effects of logging and (2) the gradual changes brought about by regrowth of veretation.

\section{SEDIMENT TRANSPOR'}

Sediment Concentration

During the 7-year calibration period, sediment concentrations of the three study streams

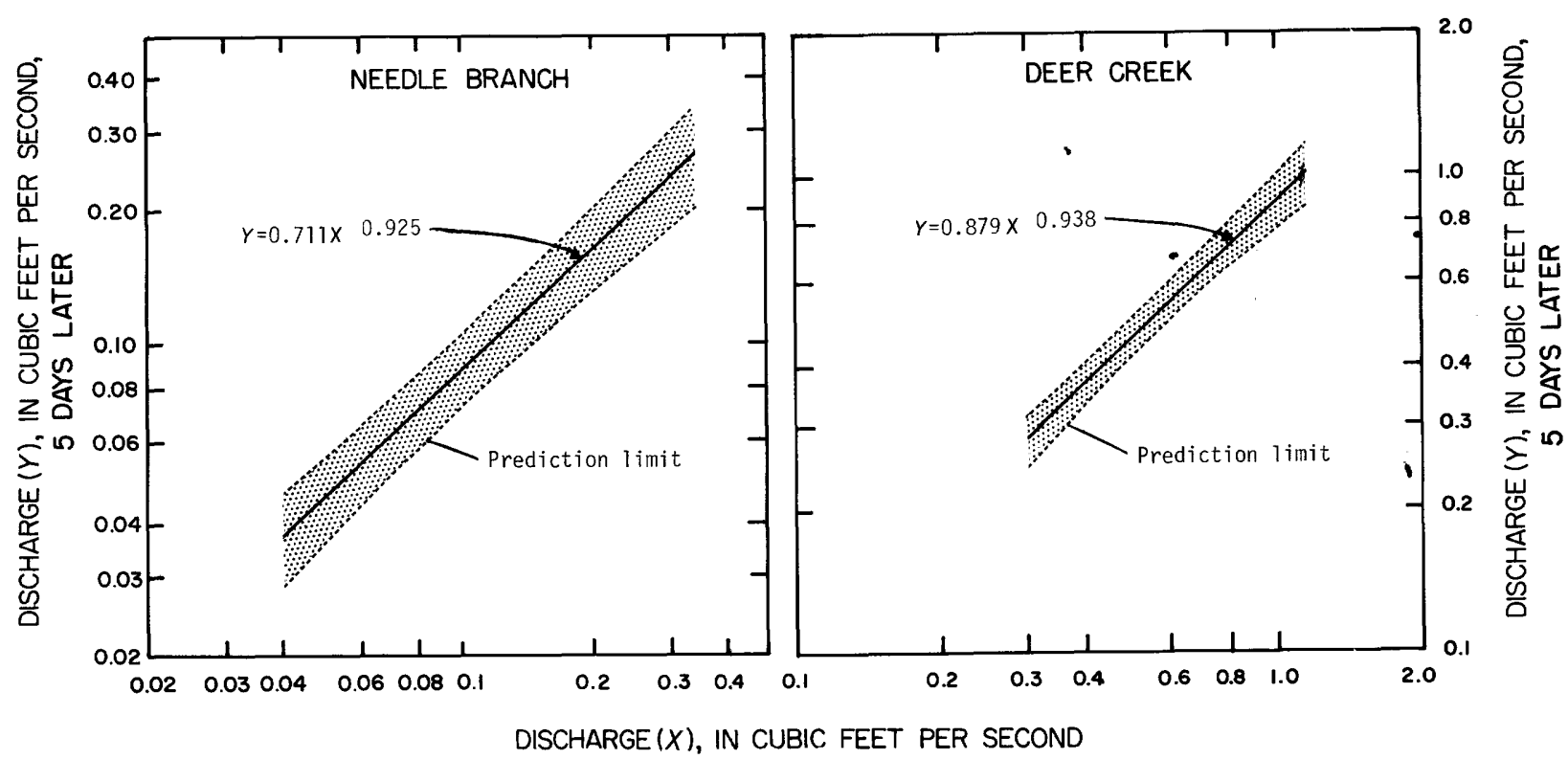

FiguRE 9.-Low-flow recession rates for Needle Branch and Deer Creek for water years 1959-65. 


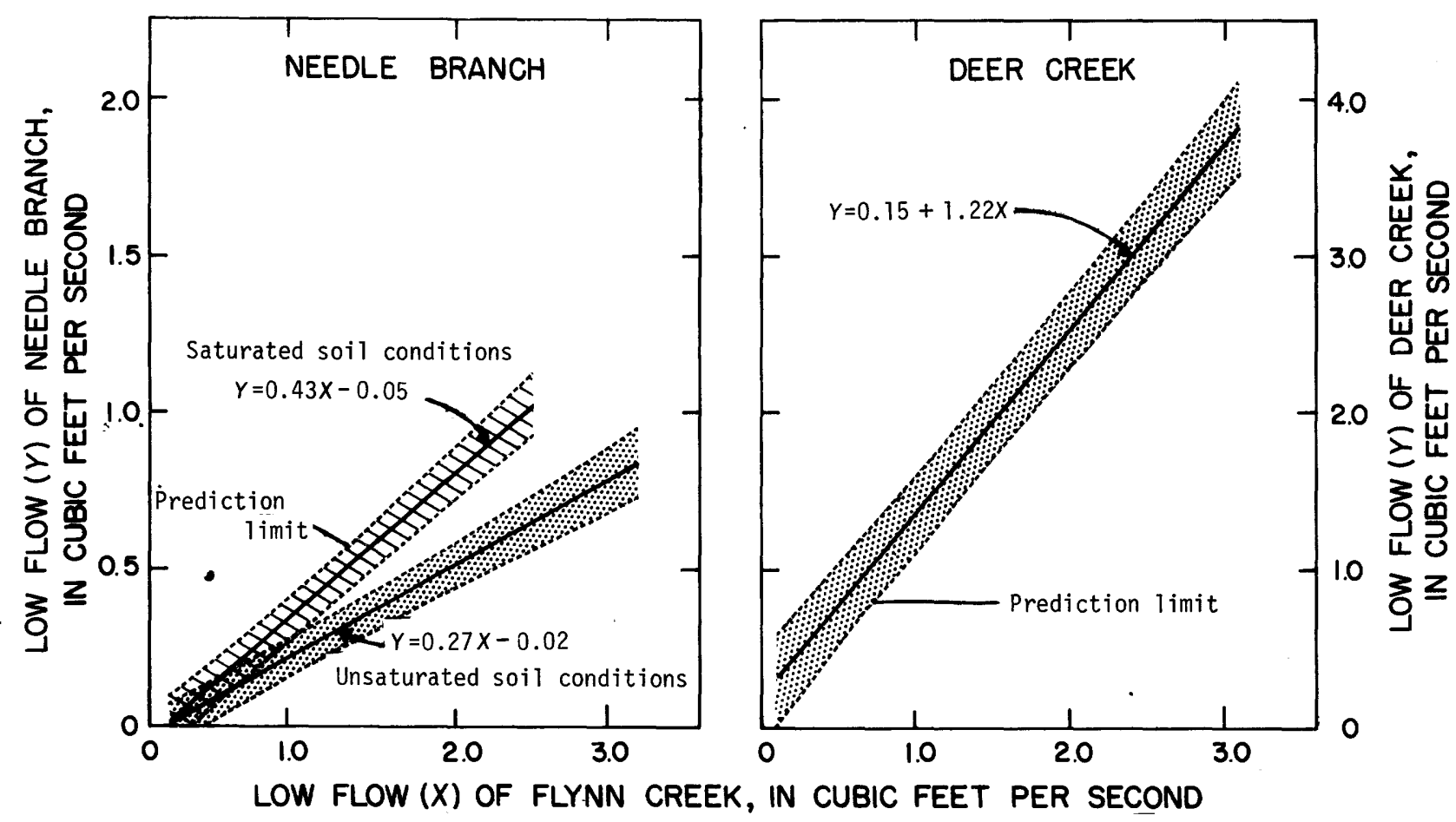

Figure 10.-Relation of low flow of Needle Branch and of Deer Creek to that of Flynn Creek for water years 1959-65.

were generally low, but they varied considerably. Minimum suspended-sediment concentrations were less than $1 \mathrm{ppm}$ (part per million); observed maximums reached $969,1,860$, and $1,480 \mathrm{ppm}$ for Needle Branch, Flynn Creek, and Deer Creek, respectively.

The duration curves given in figure 11 were developed from daily mean values of suspendedsediment concentration for the 7 years of record. These curves were used to compare the suspended-sediment concentrations of the three streams for the calibration period and should serve as a basis for comparing calibrationperiod concentrations with those for specific periods after logging. As computed from the curves, the daily suspended-sediment concentration each year averaged less than $1 \mathrm{ppm}$ on 66 , 58, and 40 days for Needle Branch, Flynn Creek, and Deer Creek, respectively. Daily concentrations averaged more than $100 \mathrm{ppm}$ on 2,3 , and 3 days for Needle Branch, Flynn Creek, and Deer Creek, respectively.

The duration curves in figure 11 show that during 2 percent of the time, when concentra- tions exceeded $50 \mathrm{ppm}$, the suspended-sediment concentrations of Flynn and Deer Creeks compared closely. However, the concentration of Flynn Creek was generally lower thar that of Deer Creek the rest of the time. The cc ncentration of Needle Branch was generally lower than that of the other two streams all the t:me.

Values of discharge-weighted mean concentration are an index of the relation of sediment load to water discharge of the three streams. These values provide a means for comparing the sediment loads of the streams. To compute the values used, the suspended-sediment load at the sampling station. was increased by the quantity of sediment deposited in the wir pools. In figure 12, the annual weighted-mean concentrations of Needle Branch and of De?r Creek are related to that of Flynn Creek. Graphic and equation forms of the regression lines are shown. For Needle Branch, the maximum deviation from the regression line was $+5 \mathfrak{s}$ percent for the 1962 water year; for Deer C.eek, the maximum deviation was +32 percent for the 1963 water year. 


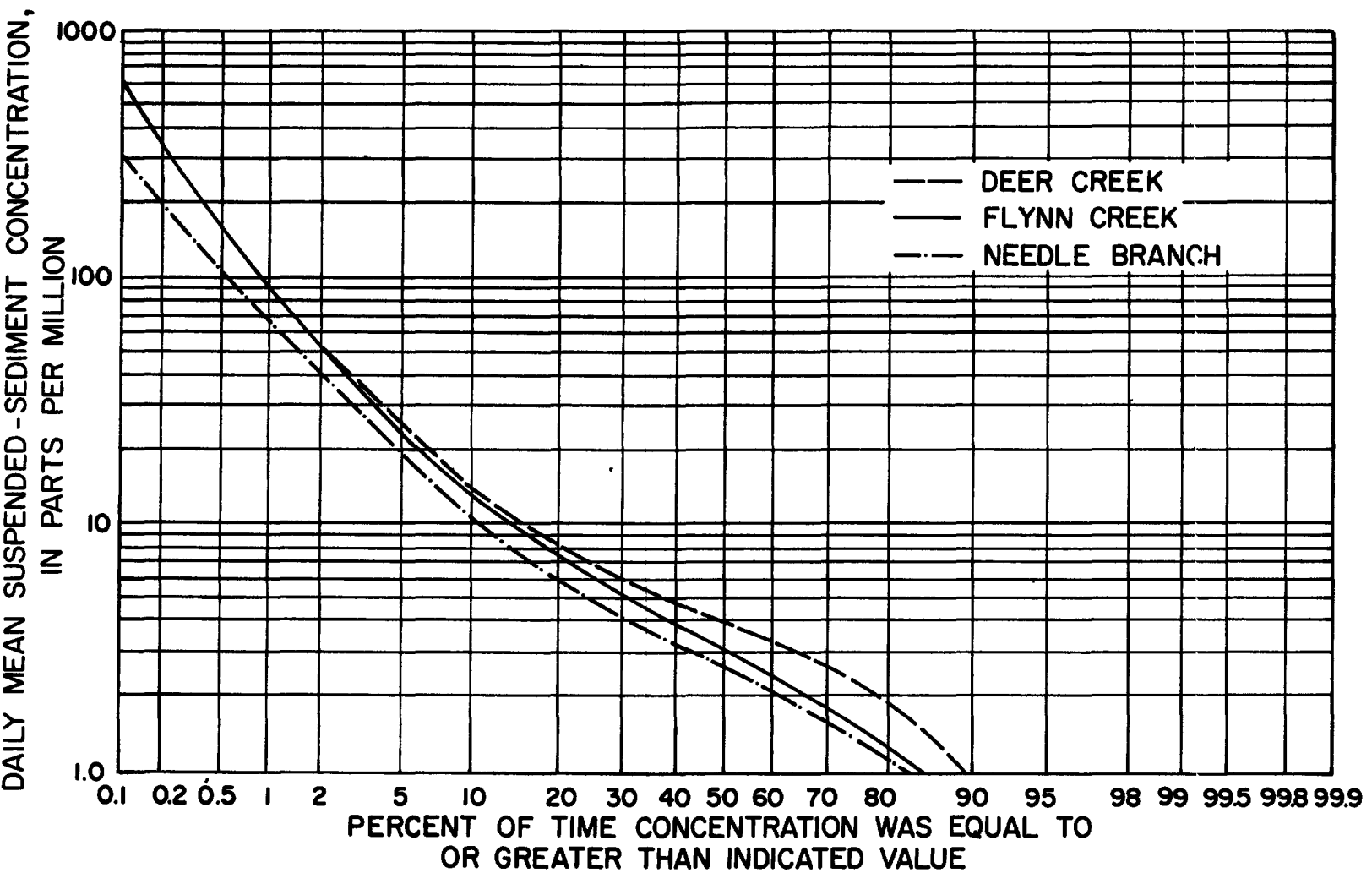

FIGURE 11.-Duration curves of suspended-sediment concentrations for streams (based on records for water years 1959-65).

As indicated by both the duration and regression studies, in terms of sediment concentration, Deer Creek relates better with Flynn Creek than does Needle Branch. However, changes caused by clear-cut logging in Needle Branch basin will probably be larger than those in Deer Creek basin and should be more conclusive, in spite of the poorer relation with Flynn Creek. As frequent short-period anomalies in sample concentrations occurred during the calibration period, it is believed that the most useful index will be the annual weightedmean concentration.

\section{Sediment Load}

The sediment load of the three study streams showed extreme seasonal variation during the calibration period. An average of 98 percent of the annual sediment load was discharged during the 5-month period November to March. Most of the load was discharged during short periods of intense rainfall and runoff. The sediment

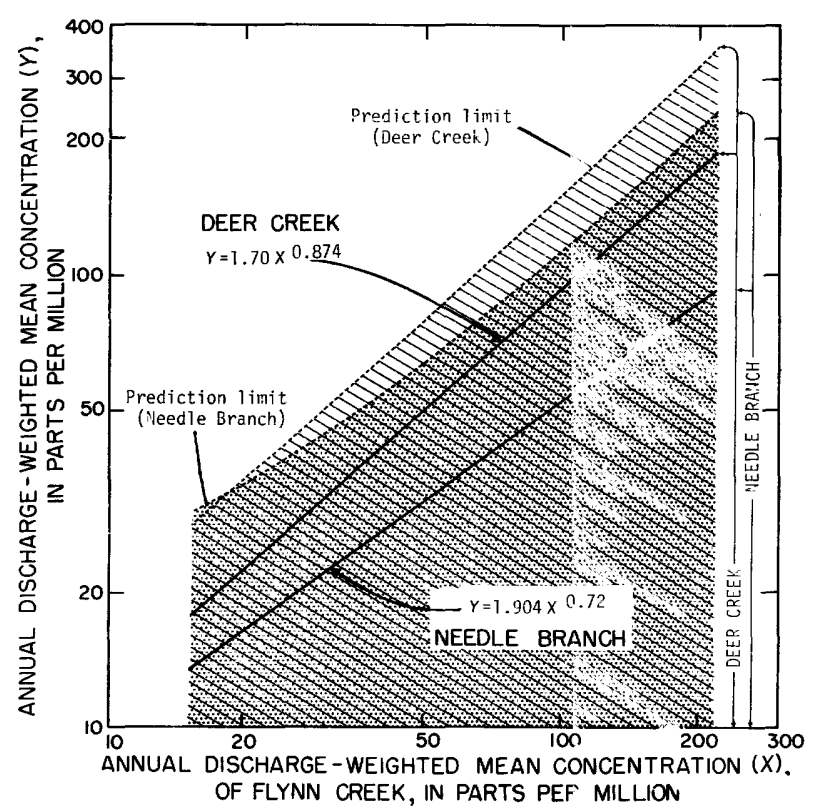

FIGURE 12.-Relation of annual discharge-weighted mean concentration of Needle Branch and of Deer Creek to that of Flynn Creek for water years 1959-65. 
load of each stream varied greatly from year to year because of changing runoff conditions caused by differences in amount and distribution of rainfall. Major floods that occurred in December 1964 and January 1965 greatly influenced the sediment load for the 1965 water year and probably will have carryover effects for the next several years. The combined sediment load of the three streams during the 2-month period was larger than the combined load for the remainder of the 7-year calibration period. The loads for the 1965 water year in the three streams were much greater than for the lowest year of record-11 times greater for Needle Branch, 19 times greater for Flynn Creek, and 12 times greater for Deer Creek.

Suspended-sediment concentrations were rarely high enough to obtain enough material for standard particle-size analysis. Therefore, data on the particle-size distribution of the sediment loads are limited to a few analyses for each stream. Table 5 gives the composition of the suspended-sediment load based on these analyses.

Two samples of deposited sediments taken in the weir pools on October 23, 1962, and October 9,1964 , were analyzed during the calibration period. The size distributions at the times of sampling are given in table 6.

Determinations of specific weight of the deposited material were made for the two samples used for particle-size analysis (table 6). The average values used for converting volume to weight were $72.4,71.4$, and 78.6 pounds per cubic foot for Needle Branch, Flynn Creek, and Deer Creek, respectively.

A variety of climatic conditions and a wide range of sediment load during the 7-year cali-

TABLE 5.-Approximate composition of suspendedsediment load during the calibration period

\begin{tabular}{|c|c|c|c|c|c|}
\hline \multirow[b]{2}{*}{ Stream } & \multicolumn{5}{|c|}{ Percentage composition by weight } \\
\hline & $\begin{array}{l}\text { Organic } \\
\text { matter }\end{array}$ & $\begin{array}{c}\text { Clay } \\
(<.004 \\
\mathrm{mm})\end{array}$ & $\begin{array}{c}\text { Silt } \\
(.004- \\
.062 \\
\text { mm })\end{array}$ & $\begin{array}{c}\text { Sand } \\
(.062- \\
2.0 \\
\mathbf{m m})\end{array}$ & $\begin{array}{c}\text { Very } \\
\text { fine } \\
\text { gravel } \\
(2.0- \\
4.0 \\
\mathrm{~mm})\end{array}$ \\
\hline Flynn Creek _---- & 10 & 12 & 32 & 46 & 0 \\
\hline Needle Branch & 24 & 14 & 26 & 34 & 2 \\
\hline Deer Creek _-_--_ & 19 & 10 & 25 & 46 & 0 \\
\hline
\end{tabular}

TABLE 6.-Particle-size distribution of sedinent deposited behind the concrete control weirs on the dates given

\begin{tabular}{|c|c|c|c|c|}
\hline \multirow[b]{2}{*}{ Stream and date } & \multicolumn{4}{|c|}{ Percentage in class by wright } \\
\hline & 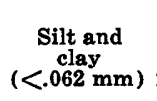 & $\begin{array}{c}\text { Sand } \\
\left(\begin{array}{c}(.062- \\
2.0 \mathrm{~mm})\end{array}\right.\end{array}$ & $\begin{array}{c}\text { Very fine } \\
\text { gravel } \\
(2.0- \\
4.0 \mathrm{~mm})\end{array}$ & $\begin{array}{c}\text { Gravel } \\
4.0- \\
64 \mathrm{~mm})\end{array}$ \\
\hline \multicolumn{5}{|l|}{ Flynn Creek: } \\
\hline $\begin{array}{l}\text { Oct. } 23,1962 \\
\text { Oct. } 9,1964\end{array}$ & $\begin{array}{l}2 \\
2\end{array}$ & $\begin{array}{l}81 \\
57\end{array}$ & $\begin{array}{r}9 \\
14\end{array}$ & $\begin{array}{r}8 \\
27\end{array}$ \\
\hline \multicolumn{5}{|l|}{ Needle Branch: } \\
\hline $\begin{array}{l}\text { Oct. 23, } 1962 \\
\text { Oct. } 9,1964\end{array}$ & $\begin{array}{l}2 \\
4\end{array}$ & $\begin{array}{l}67 \\
64\end{array}$ & $\begin{array}{l}15 \\
12\end{array}$ & $\begin{array}{l}16 \\
20\end{array}$ \\
\hline \multicolumn{5}{|l|}{ Deer Creek: } \\
\hline $\begin{array}{l}\text { Oct. 23, } 1962 \\
\text { Oct. 9, } 1964\end{array}$ & $\begin{array}{l}2 \\
1\end{array}$ & $\begin{array}{l}56 \\
36\end{array}$ & $\begin{array}{r}9 \\
10\end{array}$ & $\begin{array}{l}33 \\
\text { E3 }\end{array}$ \\
\hline
\end{tabular}

bration period provide adequate data for future comparison.

Sediment Yield

Sediment yield varied greatly from rear to year, as is illustrated in table 7 . The a verage annual yield for the calibration period was 321 and 298 tons per square mile for Flynn Creek and Deer Creek, respectively, whereas the average yield was only 166 tons per square mile for Needle Branch. Part of the reason for the lower sediment yield of Needle Branch watersl ad can be attributed to less runoff and the remainder to differences in soils, vegetation, hillslop $\mathrm{s}$, and stream gradients.

The regressions of monthly sediment yields for the study watersheds are shown in figure 13. All the relations were fairly well defined. The

TABLE 7.-Annual sediment yields, in tons per square mile, of the three principal watersheds for 1959-65

\begin{tabular}{|c|c|c|c|c|}
\hline & $\begin{array}{l}\text { Water } \\
\text { year }\end{array}$ & Flynn Creek & Needle Branch & Dier Creek \\
\hline 1959 & ---_-- - & 88 & 59 & 91 \\
\hline 1960 & -- & 65 & 41 & 91 \\
\hline 1961 & -_- & 338 & 186 & 340 \\
\hline 1962 & - - - & 138 & 141 & 118 \\
\hline 1963 & -------- & 114 & 117 & 162 \\
\hline 1964 & _..... & 226 & 184 & 213 \\
\hline \multirow[t]{2}{*}{1965} & -_...-... & 1,270 & 430 & 1.070 \\
\hline & Mean _- & 321 & 166 & 298 \\
\hline
\end{tabular}




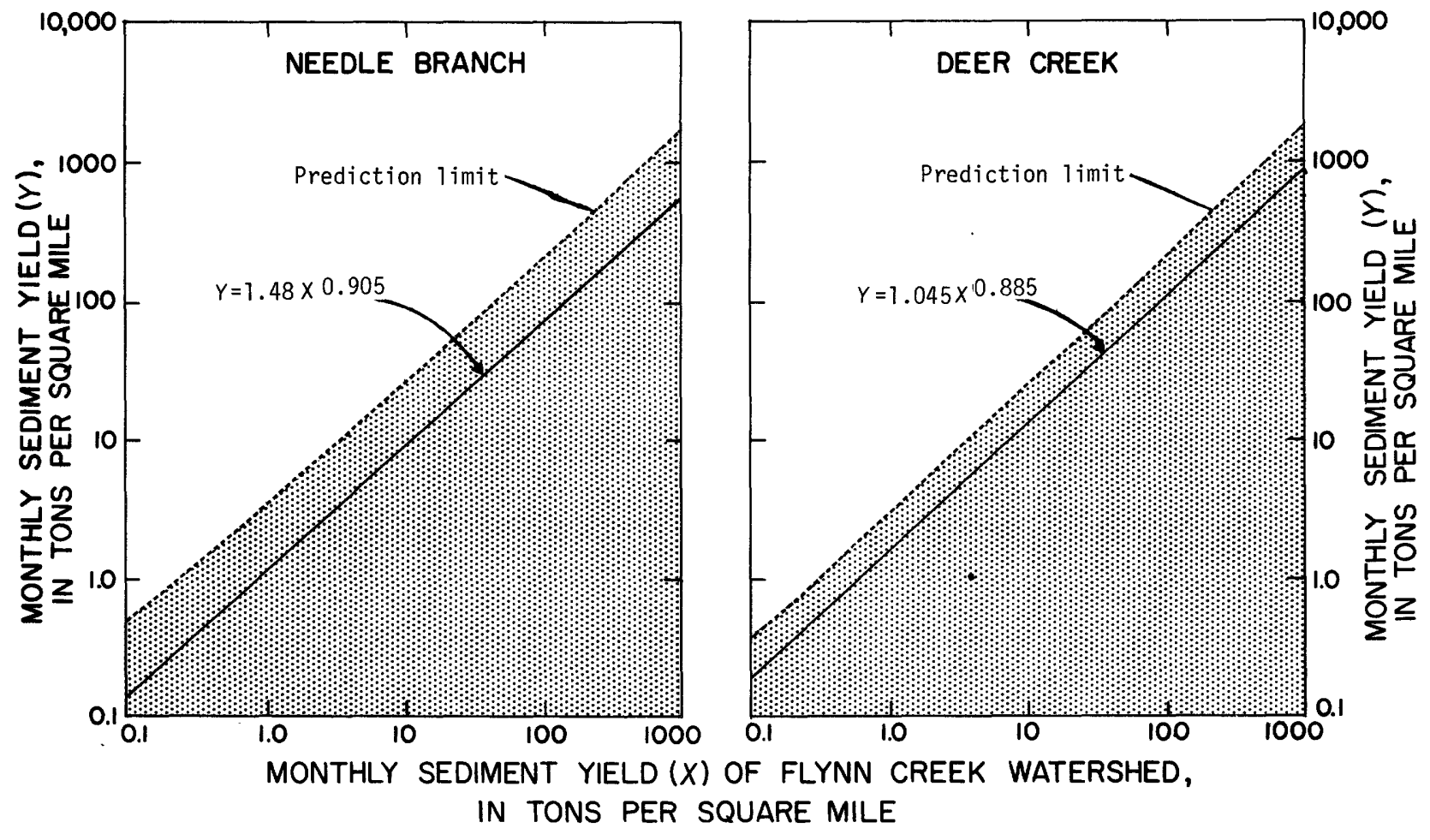

FiguRE 13.-Relation of monthly sediment yield of Needle Branch and of Deer Cre?k watersheds to that of Flynn Creek watershed for water years 1959-65.

maximum deviations from the regression line for the Needle Branch-Flynn Creek relation were +151 and -75 percent, both on the low

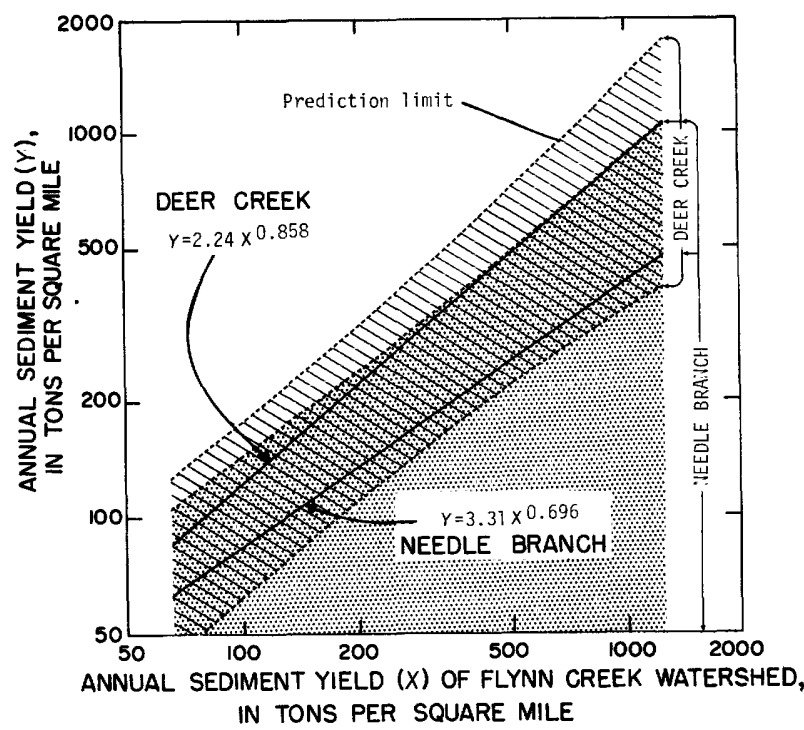

Figure 14.-Relation of annual sediment yield of Needle Branch and of Deer Creek watersheds to that of Flynn Creek watershed for water years 1959-65. end of the relation. The maximum deviations from the Deer Creek-Flynn Creek regression line were +317 and -83 percent, both also on the low end of the relation.

As expected, annual yields of the Needle Branch and Deer Creek watersheds relate to the yield of Flynn Creek watershed better than do monthly yields. Annual-yield regwession lines and equations are given in figure 14. Maximum deviations from the regression lir? were +26 and -18 percent for Deer Creek watershed and +50 and -35 percent for the Needle Branch watershed. Maximum deviations occurred in years of relatively low seliment yield.

\section{WATER TEMPERATURES}

During the calibration phase of the study, water temperatures of the thr :e principal streams agreed closely. The following table shows maximums, minimums, ant ranges of temperature in degrees Fahrenheit of the three streams during 1959-65. 


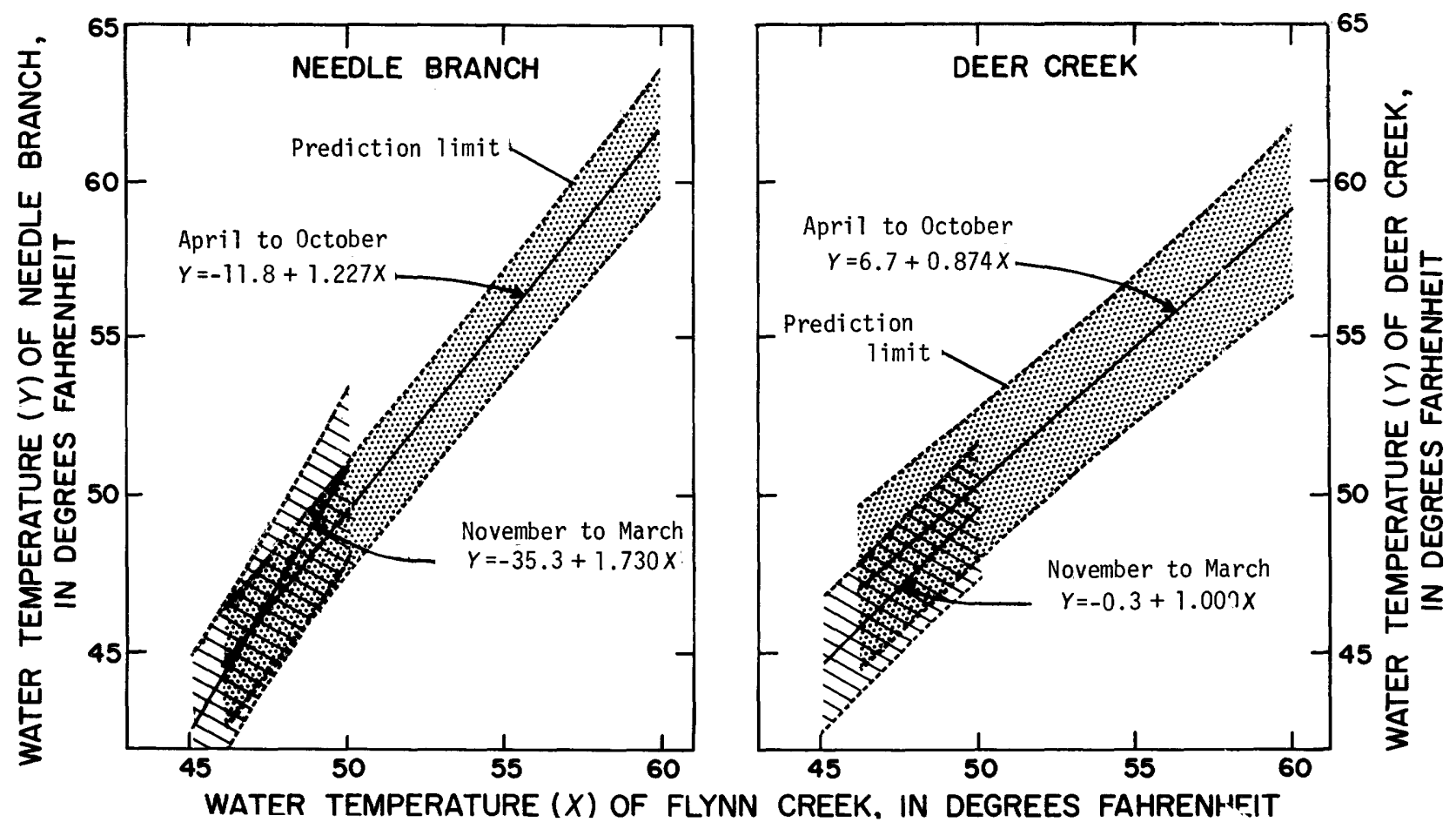

FIGURE 16.-Relation of monthly average of maximum daily water temperature of Needle Branch and of Deer Creek to that of Flynn Creek for water years 1959-65.

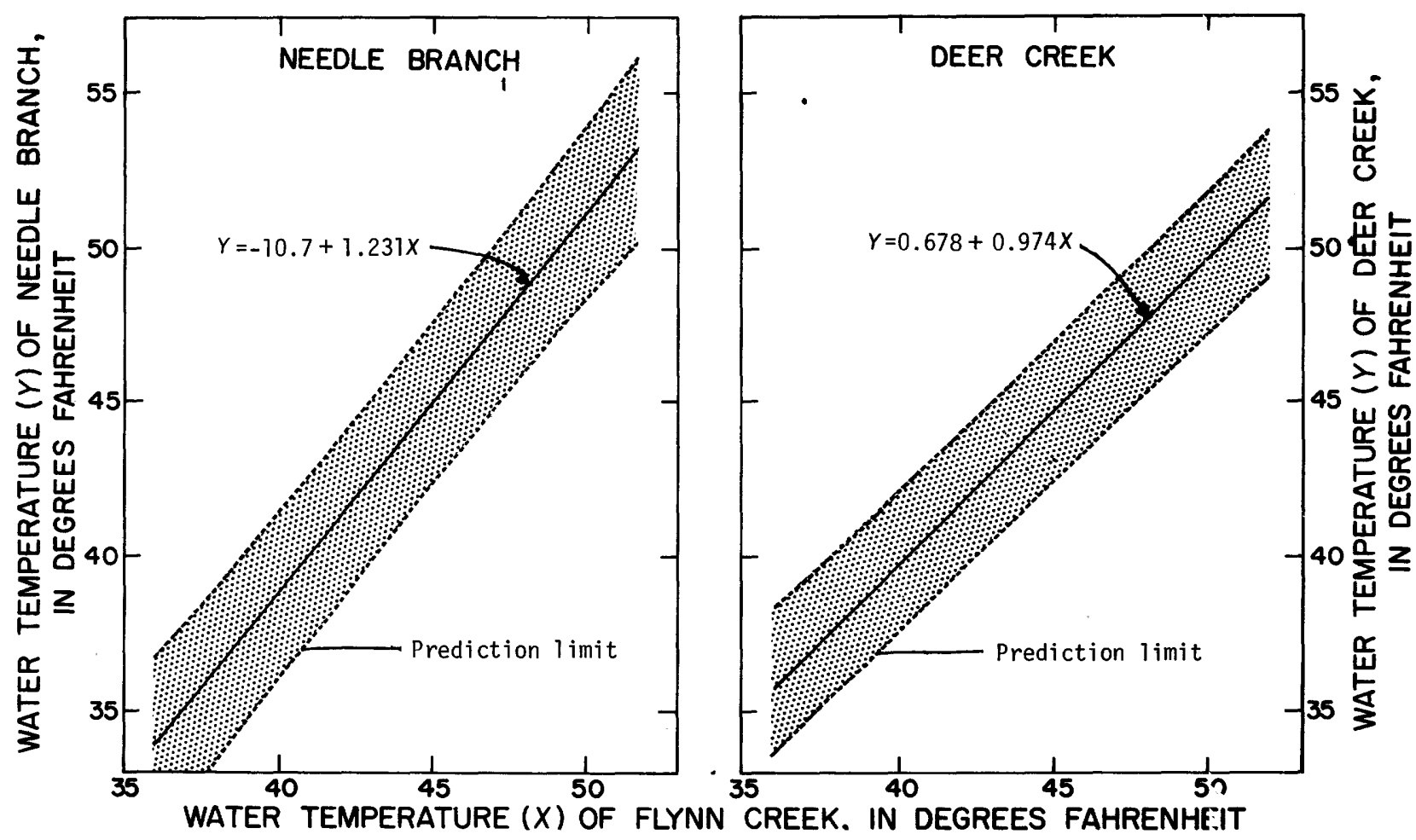

Figure 17.-Relation of minimum water temperature of Needle Branch and $c f$ Deer Creak to that of Flynn Creek for water years 1959-65. 

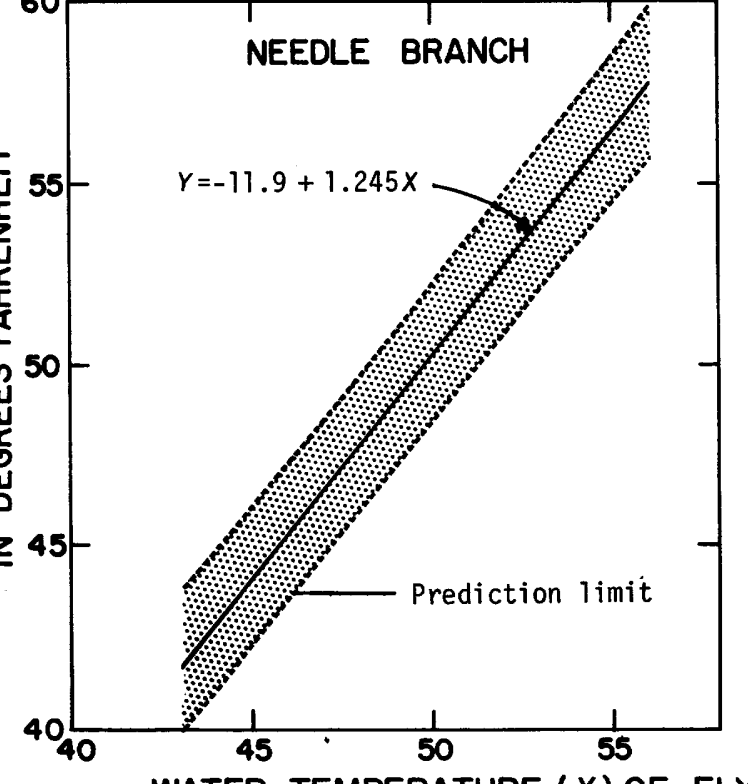

WATER TEMPERATURE $(X)$ OF FLYNN

FTGURE 18.-Relation of monthly average of minimum daily water temperature of Needle Branch and of Deer Creek to that of Flynn Creek for water years 1959-65.

and $-4.5^{\circ} \mathrm{F}$, and for Deer Creek, $+3.6^{\circ} \mathrm{F}$ and $-2.5^{\circ} \mathrm{F}$.

To evaluate the effects of logging on minimum water temperatures over a period longer than a day, a relation of the monthly averages of daily minimums was used for Needle Branch and for Deer Creek to Flynn Creek. The regression lines for these relations are shown in figure 18. The largest deviations from the regression line for Needle Branch were $+2.6^{\circ} \mathrm{F}$ and $-1.8^{\circ} \mathrm{F}$, and for Deer Creek, $+2.5^{\circ} \mathrm{F}$ and $-2.3^{\circ} \mathrm{F}$. Because some of the variations in minimums were averaged out over the monthly period, the standard errors of prediction were reduced from those for minimum water temperature.

Water-temperature range is an index of environmental influence on water temperature. Temperature range of the three streams was relatively small during the calibration period, principally because the dense vegetation shortened exposure time of the streams to solar energy. Temperature range is expected to increase significantly in Needle Branch and Deer Creek after logging. To evaluate changes, re- lations of monthly water-temperature range for Needle Branch and for Deer Creek to Flynn Creek were developed for the calibration period. Graphic and equation forms of the regression line are shown in figure 19. The largest deviations from the regression line for Needle Branch were $+4.0^{\circ} \mathrm{F}$ and $-3.9^{\circ} \mathrm{F}$, and for Deer Creek, $+4.7^{\circ} \mathrm{F}$ and $-4.3^{\circ} \mathrm{F}$.

Because the above relations have small standard errors of prediction, evaluation of th? effect of logging on maximums, minimum , and ranges of water temperature can probably be made with reasonable confidence.

\section{SUMMARY}

Hydrologic data collected during the 7-year calibration period covered a wide range of climatic and flow conditions. To define the hydrologic characteristics of the streams for the calibration period, streamflow, sediment transport, and water temperatures of Needle Branch and Deer Creek were related to that of the control stream, Flynn Creek. Prediction limits at the 95-percent level were computed for 


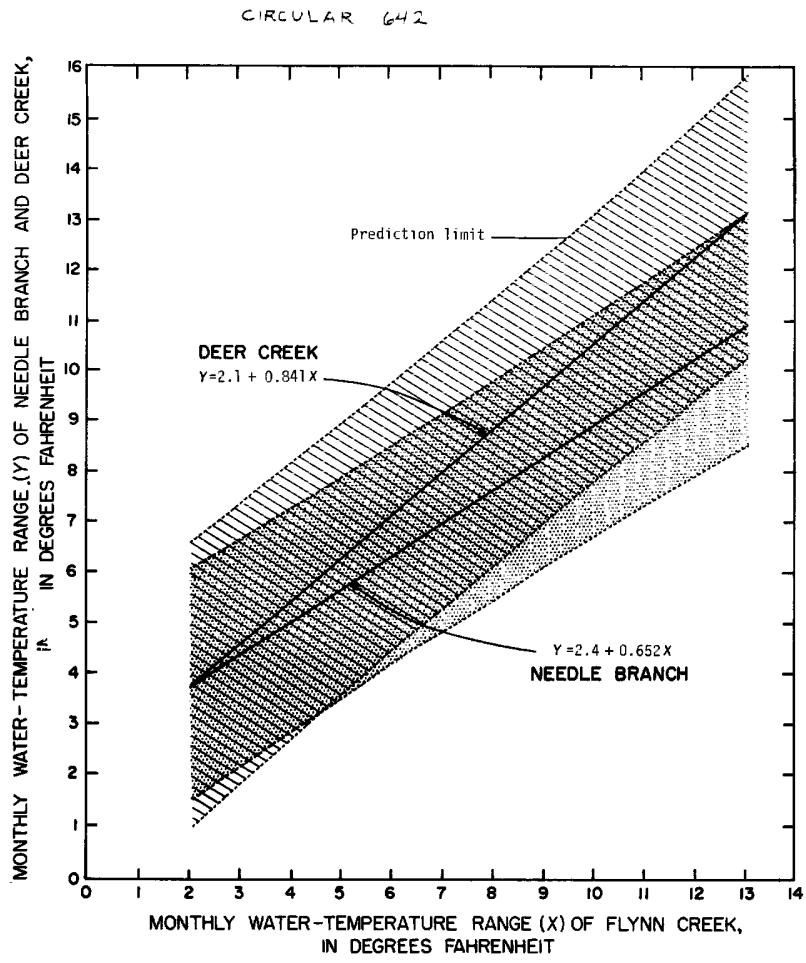

FigurE 19.-Relation of monthly water-temperature range of Needle Branch and of Deer Creek to that of Flynn Creek for water years 1959-65.

the regression line of each relation to determine the significance of future individual changes. Generally, the zones or belts between the upper and lower prediction limits were narrower for streamflow and water-temperature regressions than were those for sediment-transport regressions. Because of these narrower prediction zones, smaller individual changes in streamflow and water temperature are required to determine the significance of the changes.

If the areal distribution of rainfall does not change and if streamflow of Flynn Creek remains within the calibration range, changes caused by logging might be evaluated by use of the prediction-limit method or the covariance method. Although the prediction-limit method will be used to evaluate future individual changes, the covariance method should provide the best technique to measure the significance of future changes in the relations.

\section{SELECTED REFERENCES}

Dixon, W. J., and Massey, F. J., Jr., 1957, Introduction to statistical analysis: McGraw-Hill Book Co., $488 \mathrm{p}$.
Ezekiel, Mordecai, and Fox, K. A., 1959, Methods of correlation and regression analysis: New York, John Wiley \& Sons, Inc., 548 p.

Kohler, M. A., Nordenson, T. J., and Baker, D. R., 1959, Evaporation maps for the United States: U.S. Weather Bur. Tech. Paper 37, 13 p.

Lane, E. W., and others, 1947, Repcrt of the Subcommittee on Sediment Terminolog'? : Am. Geophys. Union Trans., v. 28, no. 6, p. 936-938.

Ostle, Bernard, 1963, Statistics in research: Ames, Iowa State Univ. Press, 585 p.

Reinhart, K. G., Eschner, A. R., and Trimble, G. R., Jr., 1963, Effect on streamflow of four forest practices in the mountains of West Virgin:a: U.S. Forest Service Research Paper NE-1, 79 p.

Richardson, Donald, 1965, Effect of lorging on runoff in upper Green River basin, Wrshington: U.S. Geol. Survey open-file rept., $45 \mathrm{p}$.

Riggs, H. C., 1963, The base-flow recession curve as an indicator of ground water: Intermat. Assoc. Sci. Hydrology, Extr. Pub. 63, p. 352-i 33 .

Schneider, W. J., and Ayer, G. R., 1961, Effect of reforestation on streamflow in central New York: U.S. Geol. Survey Water-Supply P per 1602, 61 p.

U.S. Geological Survey, 1960, Surface water supply of the United States 1959, Part 14. Pacific slope basins in Oregon and lower Columl :a River basin: U.S. Geol. Survey Water-Supply Paper 1638, 300 p.

-1961, Surface water supply of the United States, 1960, Part 14. Pacific slope basins in Oregon and lower Columbia River basin: U.S. Geol. Survey Water-Supply Paper 1718, 305 p.

1961-64, Surface water records of Oregon: U.S. Geol. Survey Water Resources Div. basic-data reports.

1964, Quality of surface waters of the United States, 1962, Parts 9-14. Colorado River basin to Pacific slope basins in Oregon and lower Columbia River basin: U.S. Geol. Survey Water-Supply Paper 1945, $691 \mathrm{p}$.

1965, Water quality records in Oregon, 1964: U.S. Geol. Survey Water Resources Div., 135 p.

-1966a, Quality of surface water: of the United States, 1959, Parts 9-14. Colorado River basin to Pacific slope basins in Oregon and lower Columbia River basin: U.S. Geol. Survey Water-Supply Paper 1645, 524 p.

1966b, Quality of surface waters of the United States, 1963, Parts 9-14. Colorado River basin to Pacific slope basins in Oregon and lower Columbia River basin: U.S. Geol. Survey WaterSupply Paper 1951, 781 p.

1966c, Water resources data for Oregon, Part 1. Surface water records, 1965: U.S. Geol. Survey Water Resources Div., 359 p. 
1966d, Water resources data for Oregon, Part 2. Water quality records, 1965: U.S. Geol. Survey Water Resources Div., 149 p.

1967, Quality of surface waters of the United States, 1961, Parts 9-14. Colorado River basin to Pacific slope basins in Oregon and lower Columbia River basin: U.S. Geol. Survey WaterSupply Paper 1885, 677 p.

1968, Quality of surface waters of the United States, 1960, Parts 9-14. Colorado River basin to Pacific slope basins in Oregon and lower Columbia River basin: U.S. Geol. Survey Water-Supply Paper 1745, 607 p.

U.S. Inter-Agency Committee on Water Resources, 1957a, The development and calibration of visual accumulation tube, Report 11 of A study of methods used in measurement and analysis of sediment loads in streams: Minneapolis, Minn., St. Anthony Falls Hydraulic Lab., 109 p.

$1957 \mathrm{~b}$, Some fundamentals of particle-size analysis, Report 12 of A study of methods used in measurement and analysis of sediment loads in streams: Wahington, U.S. Govt. Printin? Office, 55 p.

1959, Federal inter-agency sedimentation instruments and reports, Report AA of A study of methods used in measurement and anclysis of sediment loads in streams: Minneapolis, Minn., St. Anthony Falls Hydraulic Lab., 41 p.

1961. The single stage sampler for suspended sediment, Report 13 of A study of methods used in measurement and analysis of sediment loads in streams: Washington, U.S. Govt. Printing Office, $105 \mathrm{p}$.

1963, Determinations of fluvial sediment discharge, Report 14 of A study of methods used in measurement and analysis of sediment loads in streams: Washington, U.S. Govt. Printirg Office, $151 \mathrm{p}$.

Williams, R. C., 1964, Sedimentation in thr?e small forested drainage basins, Oregon: U.S. Geol. Survey Circ. 490, 16 p. 
